
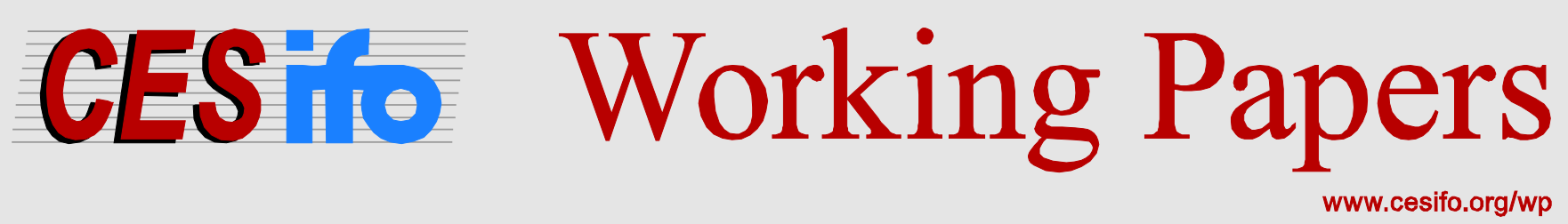

\title{
Naturally Negative: The Growth Effects of Natural Disasters
}

\author{
Gabriel Felbermayr \\ Jasmin Gröschl
}

\author{
CESIFO WORKING PAPER NO. 4439 \\ CATEgory 6: Fiscal Policy, Macroeconomics AND GROWTH \\ OCTOBER 2013
}

An electronic version of the paper may be downloaded

- from the SSRN website:

- from the RePEc website:

- from the CESifo website:

wWw.SSRN.com

Www.RePEc.org

www.CESifo-group.org/wp

\section{CESifo}




\title{
Naturally Negative: The Growth Effects of Natural Disasters
}

\begin{abstract}
Growth theory predicts that natural disasters should, on impact, lower GDP per capita. However, the empirical literature does not offer conclusive evidence. Most existing studies use disaster data drawn from damage records of insurance companies. We argue that this may lead to estimation bias as damage data and the selection into the database may correlate with GDP. We build a comprehensive database of disaster events and their intensities from primary geophysical and meteorological information. In contrast to insurance data, our GeoMet data reveal a substantial negative and robust average impact effect of disasters on growth. The worst $5 \%$ disaster years come with a growth damage of at least 0.45 percentage points. That average effect is driven mainly by very large earthquakes and some meteorological disasters. Poor countries are more strongly affected by geophysical disasters; rich more by meteorological events. International openness and democratic institutions reduce the adverse effect of disasters.
\end{abstract}

JEL-Code: O440, Q540.

Keywords: natural disasters, income per capita, openness, institutions.

Gabriel Felbermayr
Ifo Institute - Leibniz-Institute
for Economic Research
at the University of Munich
Poschingerstraße 5
Germany-81679 Munich
felbermayr@ifo.de

\author{
Jasmin Gröschl \\ Ifo Institute - Leibniz-Institute \\ for Economic Research \\ at the University of Munich \\ Poschingerstraße 5 \\ Germany - 81679 Munich \\ groeschl@ifo.de
}

October 11, 2013

We are grateful for comments and suggestions by Carsten Eckel, Niklas Potrafke, Monika Schnitzer and seminar participants at the IO and Trade Seminar at the University of Munich, the EEA meetings at Gothenburg 2013, and the VfS meeting in Goettingen 2013. We owe a special thanks to Jana Lippelt for providing excellent help with GIS software. 


\section{Introduction}

How do natural disasters affect economic activity? How does a country's integration into global financial and goods markets, or the quality of its institutions, shape this effect? In a global environment, in which climate-related natural disasters are thought to be on the rise due to global warming, these are important questions. However, using standard tools of growth empirics, the literature has come up with inconclusive answers that are often enough at odds with the standard growth theory prediction of a negative impact effect of disasters on growth and per capita income.

So far, almost all published studies have used information about the economic or human damage of disasters from the so called EM-DAT database. This collection of natural disasters is mostly based on insurance claims or news stories, but not on primary geophysical or meteorological data. The literature has raised the possibility that the nature of these data is responsible for some of the empirical puzzles and that comprehensive physical disaster intensity measures would be preferable for causal empirical analysis; see Noy (2009) and Cavallo et al. (forthcoming).

The EM-DAT database has proven a very useful tool for the analysis of direct human or monetary damages caused by natural disasters. However, for the use in growth regressions, the data suffer from two main problems. First, since the monetary damage of a given disaster is higher in a richer economy, disaster intensity measures from EM-DAT are likely to correlate with GDP per capita, the dependent variable in growth regressions. Second, if insurance coverage correlates with GDP per capita (which is quite plausible ${ }^{1}$ ) then the probability of inclusion into the database would correlate with GDP per capita. Both these problems would lead to an upward bias in empirical estimates of disasters on growth or per capita income.

In the present paper, we compile an alternative database which contains information on the physical strength of all natural disasters - earthquakes, volcanic eruptions, storms, floods, droughts, temperature extremes - that have been recorded by geophysicists or meteorologists from 1979 to 2010, essentially covering all countries of the world. Since our data is from primary geophysical or meteorological databases, we call it GeoMet data. Information about the exact coordinates of the events allows us to use ge-

\footnotetext{
${ }^{1}$ See, for instance, the information in Tables 120 and 121 in GDV-Gesamtverband der Deuschen Versicherungswirtschaft (2012).
} 
ographic information system (GIS) software in order to map disasters to countries. We show that the likelihood of some disaster with given physical magnitude being reported in EM-DAT depends strongly on the affected country's GDP per capita. This finding warns that results based on outcome-based data may suffer from selection bias.

In a next step we revisit some of the key empirical exercises in the literature. First, we test for the effect of disasters on growth. We distinguish different types of events, cover different country samples and map the effect over time. Second, we investigate some of the key mediating factors such as countries' openness to trade or finance, or their political institutions. For this purpose, we use a panel framework, so that we can control for time-invariant determinants of income such as the deep historical or geographical determinants that are usually thought to have shaped institutions or openness. Country fixed effects also control for latitude and longitude of countries, which correlate with the incidence of disasters and with institutional quality or natural resources. Moreover, following the literature, we control for a large array of observable country characteristics.

Our regressions provide clear evidence that, ceteris paribus, natural disasters do reduce real GDP per capita on impact (that is, in the year that they occur). Our key findings are: A disaster in the top 1-percentile of the disaster index distribution reduces GDP per capita by at least $6.83 \%$, while the top 5-percentile disasters cause per capita income to drop at least by $0.33 \%$, and the smallest 25 -percentile disasters cut GDP per capita by at most $0.01 \%$. Using a five year lag structure, we cannot confirm that natural disasters lead, on average, to a temporary boom following the disaster as some observers argue. Thus, on average, in our country sample, natural disasters harm development, period. If climate change brings about more natural disasters, this is unambiguously bad news. Finally, we investigate whether institutional quality and international openness help contain the economic damage of natural disasters and we find strong evidence for higher institutional quality, higher openness to trade, and higher financial openness to improve countries' ability to better cope with natural disaster shocks.

Our results are consistent with standard neoclassical growth theory. If a natural disaster (e.g., an earthquake) destroys part of a country's capital stock, then the produc- 
tion possibility frontier shifts inwards, leading to lower total output per capita. ${ }^{2}$ Subsequently, increased investment replenishes the capital stock again and, asymptotically, puts it back to its steady state level. Similarly, a disaster (e.g., a drought) lowers the average productivity of productive assets such as land, output per capita must fall. In terms of growth rates, theory predicts growth to be lower than trend on impact and, under the right institutions, higher than trend thereafter. ${ }^{3}$ Alternative hypotheses revolve around the idea that the destruction of physical capital allows the affected economy to replace outdated equipment and structures faster than along the balanced growth path (Caballero and Hammour, 1994). This may add to a temporary boom following the disaster. However, a lack of appropriate institutions, inadequate financing conditions, or limited access to international markets may hamper the catching-up process. Hence, again, the prediction is that a natural disaster lowers GDP per capita on impact. ${ }^{4}$ Our findings confirm that the immediate effect of a disaster on GDP per capita is robustly negative; while, using the same econometric setup, outcome-based EM-DAT data yields positive (albeit insignificant) estimates.

Also, our results on the mediating factors are plausible and in line with standard arguments. For example, following a disaster, an open economy can step up investment at unchanged consumption, thereby allowing faster convergence back to the balanced growth path. Similarly, safer property rights in more established democracies encourage domestic and foreign investment in the affected economy, speeding up recovery quickly after impact. These findings suggest that our GeoMet data passes the credibility test.

Our dataset is likely to be useful in other applications than the one of this paper. Natural disasters, gauged by geophysical or meteorological intensity measures, provide variation that is plausibly exogenous to economic or societal outcomes and can thereby serve as instrumental variable for many empirical questions. It can also be used to provide more direct tests for the mediating factors discussed in this paper, e.g., by testing for the effect of disasters on imports or exports, or on investment.

\footnotetext{
${ }^{2}$ Assuming that the disaster has no major effect on population size.

${ }^{3}$ Strictly speaking, in continuous time models, the growth rate at impact is not defined. Our statements refer to discrete time data as reported in official GDP statistics.

${ }^{4}$ See Hallegatte and Przyluski (2010) for illustrations of the disaster effect over time. Other theoretical applications on the impact of natural disaster occurrence on output dynamics do not provide a clear cut prediction either (see, i.e., Soretz, 2007; Hallegatte and Dumas, 2009; Narita et al., 2010; Ikefuji and Horii, 2012).
} 
The remainder of this paper is structured as follows: Section 2 discusses the available disaster data, describes the construction of GeoMet, and compares key features of the two types of datasets. Section 3 analyzes the impact of natural disasters on GDP per capita and Section 4 studies how that impact is shaped by institutions or openness. Finally, Section 5 concludes.

\section{Disaster Data}

\subsection{State of the Literature}

Until now, must studies on the growth effects of natural disasters have used the Emergency Events Database (EM-DAT), provided by the Centre for Research on the Epidemiology of Disasters (CRED) at Université Catholique de Louvain. "The database is compiled from various sources, including UN agencies, non-governmental organizations, insurance companies, research institutes and press agencies" ${ }^{5}$ It contains outcome data: it reports the number of people killed or affected (i.e., injured or rendered homeless) or the estimated monetary damage. The insurance firm Munich Re provides a similar database, NatCatSERVICE, which is - in contrast to EM-DAT - not publicly available.

With very few exceptions, the growing body of empirical literature studying the effect of natural disasters on economic outcomes has used EM-DAT data. Table 1 provides an overview of the major papers. ${ }^{6}$ Existing works differ with respect to the exact definition of the dependent variable, with respect to whether the disaster variable is based on information about outcomes (economic or human damage) or on a measure of physical strength, with respect to the country sample employed, and whether the units of observation are country-year combinations or events, not to talk about the details of the econometric specification. Table 1 does not intend to give a complete and comprehensive overview of existing work. Rather, it shows that empirical

\footnotetext{
${ }^{5}$ http://www.emdat.be/.

${ }^{6}$ The table does not make any claim to offer an exhaustive account of the literature. Other studies look into further consequences of disasters, for instance, Yang (2008) examines the consequences of disasters on international financial flows using Hurricane track data. Miguel et al. (2004) use precipitation data to investigate the impact of economic shocks on civil conflict in Sub-Saharan Africa, and Brückner and Ciccone (2011) examine the democratic consequences of economic shocks caused by exogenous weather variation in Sub-Saharan Africa. citetbaker2013uncertainty use natural disasters from the EM-DAT data base to identify the causal link between uncertainty and economic growth.
} 
evidence has produced inconclusive results so far. The 14 studies surveyed contain 368 point estimates of the effect of disasters on GDP per capita. Virtually all studies use the outcome-based data of EM-DAT, only two studies make use of geophysical or meteorological data, but specialize on specific types of disasters. About $38 \%$ of all estimates are statistically insignificant at the $10 \%$ level; about $44 \%$ of the statistically significant effects are positive, while the remaining $56 \%$ of significant estimates are negative.

TABLE 1

Key characteristics of major published empirical papers

\begin{tabular}{|c|c|c|c|c|c|}
\hline $\begin{array}{l}\text { Study (Au- } \\
\text { thors, Journal) }\end{array}$ & $\begin{array}{l}\text { Dependent } \\
\text { variable }\end{array}$ & $\begin{array}{l}\text { Disaster } \\
\text { Data }\end{array}$ & Sample & $\begin{array}{l}\text { Unit of ob- } \\
\text { servation }\end{array}$ & Main Finding \\
\hline $\begin{array}{l}\text { Albala- } \\
\text { Bertrand } \\
\text { (1993), WD }\end{array}$ & $\begin{array}{l}\text { GDP } \\
\text { growth }\end{array}$ & geo/meteo & $\begin{array}{l}\text { Latin } \\
\text { America }\end{array}$ & events & Neutral or positive. \\
\hline $\begin{array}{l}\text { Skidmore and } \\
\text { Toya (2002), EI }\end{array}$ & $\begin{array}{l}\text { GDP } \\
\text { growth }\end{array}$ & outcomes & world & countries & $\begin{array}{l}\text { No effect of geophysical disasters, } \\
\text { positive for climatic disasters. }\end{array}$ \\
\hline $\begin{array}{l}\text { Kahn (2005), } \\
\text { RESTAT }\end{array}$ & $\begin{array}{l}\text { killed, } \\
\text { affected }\end{array}$ & outcomes & world & events & $\begin{array}{l}\text { Lower monetary damages of disas- } \\
\text { ters in advanced economies and in } \\
\text { countries with better institutions. }\end{array}$ \\
\hline $\begin{array}{l}\text { Raddatz (2007), } \\
\text { JDE }\end{array}$ & GDP level & outcomes & $\begin{array}{l}\text { low- } \\
\text { income }\end{array}$ & countries & $\begin{array}{l}\text { No effect of geological disasters, } \\
\text { negative for climatic disasters. }\end{array}$ \\
\hline $\begin{array}{l}\text { Toya and Skid- } \\
\text { more (2007), } \\
\text { ECON LETT }\end{array}$ & $\begin{array}{l}\text { killed, } \\
\text { damage } \\
\text { over GDP }\end{array}$ & outcomes & $\begin{array}{l}\text { world, } \\
\text { OECD }\end{array}$ & countries & $\begin{array}{l}\text { Better institutions, better school- } \\
\text { ing, and higher openness mitigate } \\
\text { negative effect. }\end{array}$ \\
\hline $\begin{array}{l}\text { Hochrainer } \\
\text { (2009), WBPRP }\end{array}$ & $\begin{array}{l}\text { GDP } \\
\text { growth }\end{array}$ & outcomes & world & countries & $\begin{array}{l}\text { Negative effects, depending on size } \\
\text { of the shock. }\end{array}$ \\
\hline $\begin{array}{l}\text { Leiter et al. } \\
\text { (2009), ERE }\end{array}$ & $\begin{array}{l}\text { value } \\
\text { added, em- } \\
\text { ployment }\end{array}$ & outcomes & Europe & $\begin{array}{l}\text { firms, } \\
\text { regions }\end{array}$ & Positive. \\
\hline Noy (2009), JDE & $\begin{array}{l}\text { GDP } \\
\text { growth }\end{array}$ & $\begin{array}{l}\text { outcomes } \\
\& \\
\text { geo/meteo }\end{array}$ & $\begin{array}{l}\text { world, de- } \\
\text { veloping }\end{array}$ & countries & $\begin{array}{l}\text { Negative effect with monetary dam- } \\
\text { age, no effect with alternative mea- } \\
\text { sures. }\end{array}$ \\
\hline $\begin{array}{l}\text { Raddatz (2009), } \\
\text { WBPRP }\end{array}$ & $\begin{array}{l}\text { GDP } \\
\text { growth }\end{array}$ & outcomes & world & countries & Negative effect of climate disasters. \\
\hline $\begin{array}{l}\text { Strobl (2011), } \\
\text { RESTAT }\end{array}$ & $\begin{array}{l}\text { GDP } \\
\text { growth }\end{array}$ & $\begin{array}{l}\text { meteo \& } \\
\text { outcomes }\end{array}$ & developing & countries & Negative effect of hurricanes. \\
\hline $\begin{array}{l}\text { Loayza et al. } \\
\text { (2012), WD }\end{array}$ & $\begin{array}{l}\text { GDP } \\
\text { growth }\end{array}$ & outcomes & $\begin{array}{l}\text { world, de- } \\
\text { veloping }\end{array}$ & countries & $\begin{array}{l}\text { Positive impact of floods, negative } \\
\text { effect of droughts (in developing } \\
\text { countries), no effect of earthquakes } \\
\text { and storms. }\end{array}$ \\
\hline
\end{tabular}


Table 1 - continued

\begin{tabular}{|c|c|c|c|c|c|}
\hline $\begin{array}{l}\text { Study (Au- } \\
\text { thors, Journal) }\end{array}$ & $\begin{array}{l}\text { Dependent } \\
\text { variable }\end{array}$ & $\begin{array}{l}\text { Disaster } \\
\text { data }\end{array}$ & Sample & $\begin{array}{l}\text { Unit of ob- } \\
\text { servation }\end{array}$ & Main Finding \\
\hline $\begin{array}{l}\text { Fomby et al. } \\
\text { (2013), JAE }\end{array}$ & $\begin{array}{l}\text { GDP } \\
\text { growth }\end{array}$ & outcomes & $\begin{array}{l}\text { world, de- } \\
\text { veloping }\end{array}$ & countries & $\begin{array}{l}\text { Moderate disasters can have } \\
\text { positive effect; positive effect of } \\
\text { floods, negative effect of storms } \\
\text { and droughts, mixed evidence on } \\
\text { earthquakes. }\end{array}$ \\
\hline $\begin{array}{l}\text { Felbermayr and } \\
\text { Gröschl (2013), } \\
\text { EER }\end{array}$ & GDP level & outcomes & world & countries & $\begin{array}{l}\text { Depending on the sample, neutral, } \\
\text { positive or negative effects. }\end{array}$ \\
\hline $\begin{array}{l}\text { Cavallo et al. } \\
\text { (forthcoming), } \\
\text { RESTAT }\end{array}$ & GDP level & outcomes & world & events & $\begin{array}{l}\text { No effect of disasters; only very } \\
\text { large have a negative effect, but not } \\
\text { when controlling for political up- } \\
\text { heaval. }\end{array}$ \\
\hline
\end{tabular}

Note: 'outcomes' refer to economic or human damage, 'geo/meteo' to measures of physical strength. All GDP measures are in real and per capita terms. WD...World Development, EI...Economic Inquiry, RESTAT...Review of Economics and Statistics, JDE...Journal of Development Economics, ECON LETT...Economics Letters, ERE...Environmental and Resource Economics, JAE...Journal of Applied Economics, EER...European Economic Review, WBPRP... World Bank Policy Research Paper.

In EM-DAT (or similar databases), disaster intensity measures are a function of economic development. ${ }^{7}$ However, estimating causal relations between disasters and economic variables, such as income per capita, migration, or trade, requires measures on the disaster impact that do not correlate with those outcomes. ${ }^{8}$ Noy (2009) and Cavallo et al. (forthcoming) argue that comprehensive physical disaster intensity measures would be preferable for causal empirical analysis, but deplore that such data is not available for cross-country analyses yet.

In this paper, we fill that gap. We propose a novel and comprehensive dataset, called GeoMet, that contains exogenous measures of physical disaster intensity, such as Richter scale and wind speed. It covers the years 1979 to 2010 . We utilize data from five primary sources mainly used in geophysics or climatology. Our database contains information on the intensity of all disaster events, the month, year and country of occurrence. These data can be merged to the damage records of EM-DAT. Moreover, it can be collapsed on the country-year level. This allows running standard growth regressions

\footnotetext{
${ }^{7}$ See Kahn (2005) and Toya and Skidmore (2007) for a discussion.

${ }^{8}$ Nonetheless, outcome-based measures of disasters are often treated as exogenous variables in the literature.
} 
of the impact of disasters on economic activity using econometric panel tools. After discussing the primary sources, we compare our GeoMet data to existing data sources and highlight the shortcomings of the latter for causal analysis.

\subsection{Primary Sources}

Earthquakes. Our data on seismic activity stem from the Incorporated Institute for Seismology (IRIS), which lists the strength (Richter scale) of every earthquake on the planet by latitude and longitude of the epicenter. We map the data to countries using Flinn-Engdahl codes ${ }^{9}$ and geographic information system (GIS) software ${ }^{10}$. We consider earthquakes on land and those happening right off the coastline of a specific country. We use the maximum realization within a single earthquake event as the measure of physical disaster intensity of that earthquake. The highest value on the Richter scale recorded in our data is 8.8 and was measured on the Philippines in February 2006.

Volcanic Eruptions. The Global Volcanism Program of the Smithsonian Institution measures volcanic eruptions and specifies the magnitude by the Volcanic Explosivity Index (VEI). ${ }^{11}$ The Global Volcanism Program documents the eruption start date and stop date of all volcanic eruptions. The listed VEI is the highest VEI reached during the entire eruptive episode. The highest reported VEI in our dataset is 6 , which was recorded for an outbreak by the Pinatubo on the Philippines in 1991. We use the maximum VEI as our measure of the intensity of volcanic eruptions.

Storms. We use two primary data sources for wind speed: the International Best Track Archive for Climate Stewardship (IBTrACS) and the Global Surface Summary of Day (GSOD) data. The IBTrACS data (version v03r03) is provided by the National Climatic Data Center of the National Oceanic and Atmospheric Administration (NOAA) which

\footnotetext{
${ }^{9}$ The Flinn-Engdahl seismic and geographical categorization of regions breaks the world into regions based on geographic and political boundaries, where each region is assigned a unique number. Regional boundaries are defined at one-degree intervals and may thus differ from national boundaries.

${ }^{10}$ GIS uses geographical location as the key index variable to relate information to specific countries, or regions. Any variable that can be located spatially can be referenced using GIS software. Information, such as precipitation in a certain region, storm or epicenter location anywhere on the globe may be mapped to countries using information on their geographical occurrence, such as longitude and latitude, respectively.

${ }^{11}$ The Volcanic Explosivity Index is coded on a logarithmic scale and is defined over the interval 0 to 8. The VEI combines the volume of tephra ejected and the height of the eruption cloud.
} 
records data of individual hurricane events, positions (latitude and longitude) of hurricane centers at 6-hourly intervals, combined with intensity information (wind speed in knots and barometric pressure). The data incorporate information from a variety of sources, such as reconnaissance aircraft, ships, and satellites. ${ }^{12}$ The raw 'best track' data give no indication on affected countries. We use geographic information system (GIS) software to map hurricane position data to affected countries. Not only do we consider positions (latitude and longitude) on land, but we also consider positions off the coastline of a country. ${ }^{13}$ To capture tornadoes, and winter and summer storms (not captured by the IBTrACS data), the hurricane track data is matched to daily data of the GSOD data (version 7) on maximum wind speed and wind gust. This dataset includes records of wind speed from over 9000 worldwide stations and is produced by the National Climatic Data Center (NCDC). GSOD uses daily summaries of hourly observations contained in the Integrated Surface Data (ISD). We collapse daily extremes on wind speed and wind gust over all stations on a country basis. Combining both datasets, we obtain a measure that brings together wind speed from the hurricane track data and wind speed from GSOD. We use the maximum total wind speed in knots on a country basis as our disaster intensity measure for storms.

Floods and Droughts. Precipitation data are recorded by the Goddard Space Flight Center of the National Aeronautics and Space Administration (NASA) in the Global Precipitation Climatology Project (GPCP). The GPCP combines weather station rainfall gauge measures and satellite information. Average monthly precipitation data are provided in millimeters (mm) for 2.5 latitude and longitude degree grid nodes. Following Miguel et al. (2004) and Brückner and Ciccone (2011), we bring the data to the country level by matching rainfall estimates per node to the corresponding country using GIS software and we average rainfall across nodes to produce an estimate of total monthly rainfall per country. ${ }^{14}$ Our principal measure of weather variation is the difference in monthly rainfall in $\mathrm{mm}$, which we define as the proportional deviation of monthly rainfall from average monthly rainfall of the entire available time period (1979-2010). We

\footnotetext{
${ }^{12}$ Since the 1960s most of the data stem from satellites (Chu et al., 2002; Yang, 2008).

${ }^{13}$ As tropical storms and hurricanes can be relatively wide, tropical storm-force and hurricane-force winds may cause destruction even though they did not make landfall (National Hurricane Center, 1999).

${ }^{14}$ If no degree node fell within the national boundaries of a country, we assigned the rainfall measures from the nearest node(s) to their borders.
} 
distinguish two disaster types, floods and droughts. We measure flooding events by the positive difference in monthly precipitation. Droughts are, however, different in the sense that a single dry month usually does not cause a drought, but several months in a row or within a year might do so. For this reason, we create an indicator variable for droughts, which takes the value of unity if at least three subsequent months have rainfall below $50 \%$ of the long-run average monthly mean, or if at least five months within a year have rainfall below $50 \%$ of the long-run monthly mean, and zero otherwise.

Extreme temperature events. Temperature data also stem from (GSOD, version 7) which includes records of temperature from over 9000 worldwide stations and is produced by the National Climatic Data Center (NCDC). ${ }^{15}$ The GSOD dataset uses daily summaries of hourly observations contained in the Integrated Surface Data (ISD). We collapse daily temperature extremes over all stations on a country basis. Our disaster intensity measure for temperature extremes is the percentage difference between the maximum temperature in one month from the corresponding long-run (1979-2010) monthly mean. Strong positive deviations are interpreted as heat waves, strong negative ones as cold waves.

\subsection{A New Data Set: GeoMet}

In the following, we construct two datasets: (i) an event-based set, which merges the GeoMet data physical disaster intensity measures with the measures of material and human damage reported in EM-DAT, ${ }^{16}$ and (ii) a data set that matches yearly indices of disaster intensity per country to macroeconomic variables.

Virtually all earthquakes, volcanic eruptions, storms, floods, droughts, and extreme temperature events reported by EM-DAT can be also found in GeoMet, ${ }^{17}$ too, but the opposite is not true: Out of 10,448 earthquakes with strength at least 5 on the Richter scale, EM-DAT reports only $6.2 \%$. That rate is highest for the strongest earthquakes (40.9\%), but falls quickly with decreasing earthquake intensity. Volcano eruptions are

\footnotetext{
${ }^{15}$ Data are converted from degrees Fahrenheit into degrees Celsius using the common formula $\left({ }^{\circ} \mathrm{F}-\right.$ 32) $* 5 / 9$.

${ }^{16}$ We also match the GeoMet data to the NatCatSERVICE database of Munich Re. Note that the Munich Re database is not publicly available. Results based on NatCatSERVICE (reported in the Appendix) are similar to those based on EM-DAT.

${ }^{17}$ The exact numbers are $99.95,97.16,99.98,99.99,100.00,99.99$ percent, respectively.
} 
better covered, with $14.7 \%$ of all events with VEI measure higher than 2 being included into EM-DAT and half of all events stronger than VEI 4 covered. ${ }^{18}$

TABLE 2

Physical strength and the costs of large natural disasters

\begin{tabular}{|c|c|c|c|c|c|c|c|c|}
\hline \multirow[b]{2}{*}{$\begin{array}{l}\text { Large Disaster } \\
\text { Type }\end{array}$} & \multirow[b]{2}{*}{ Obs. } & \multicolumn{4}{|c|}{ Physical Magnitude } & \multicolumn{3}{|c|}{ Costs Reported in EMDAT (Mean in \%) } \\
\hline & & Mean & Std. Dev. & Minimum & Maximum & $\begin{array}{l}\text { Killed over } \\
\text { population }\end{array}$ & $\begin{array}{c}\text { Affected over } \\
\text { population }\end{array}$ & $\begin{array}{l}\text { Damage over } \\
\text { GDP }\end{array}$ \\
\hline Earthquake & 146 & 6.2 & 0.986 & 3.7 & 8.6 & 0.023 & 1.401 & 1.404 \\
\hline Volcano & 9 & 3.44 & 1.424 & 1 & 6 & 0.009 & 1.609 & 0.542 \\
\hline Storm & 494 & 72.66 & 25.884 & 12 & 150 & 0.002 & 3.644 & 11.465 \\
\hline Flood & 467 & 0.389 & 0.783 & 0.003 & 13.549 & 0.001 & 3.092 & 0.359 \\
\hline Drought & 253 & -0.360 & 0.266 & -0.983 & -0.001 & 0.143 & 18.027 & 1.526 \\
\hline Extreme Temperature & 34 & 0.141 & 0.257 & 0.001 & 1.325 & 0.008 & 10.214 & 0.454 \\
\hline
\end{tabular}

Note: Matched event-based dataset (EM-DAT + GeoMet), covering the years 1979-2010. The decision rule on large disasters in EM-DAT builds on the convention of Munich Re (2006). Large-scale disasters are defined as events that (i) caused 1,000 or more injured or dead; (ii) affected 100,000 or more persons; or (iii) caused a monetary damage of 1 billion or more US dollars.

Table 2 combines GeoMet and EM-DAT data to report the physical intensity and the monetary or human costs of natural disasters. It focuses on large disasters, as defined in the EM-DAT data base. In principle, this allows to find the intensity thresholds beyond which disasters can be deemed "big". For earthquakes, this works: the threshold has a meaningful value of 3.7 on the Richter scale; for the other disaster types, the thresholds are very close to zero, indicating that EM-DAT does sometimes report substantial damage from events that had very small physical intensity. Averages are more interesting. Large earthquakes have a mean Richter scale of 6.2, while large volcanic eruptions have a mean VEI of 3.44. Storms are listed as large-scale with a mean wind speed of 72.66 knots, a flood is large with a mean divergence in monthly precipitation of 0.389 $\mathrm{mm}$, droughts are large in scale with a negative mean difference in monthly precipitation of $0.360 \mathrm{~mm}$, and extreme temperature events have a mean monthly difference of $0.141^{\circ} \mathrm{C}$. While droughts cause the highest death toll and affected population, storms are, on average, responsible for the largest monetary damages. ${ }^{19}$

Following Kahn (2005), Table 3 reports the results of linear regressions of material or

\footnotetext{
${ }^{18}$ Table B-I in the Appendix provides full information on all events, as well as the associated damage indicators from EM-DAT.

${ }^{19}$ Figure in the Web Appendix shows that disasters reported by an outcome-based data base such as EM-DAT are systematically stronger than those reported by geophysical or meteorological sources and compiled in GeoMet.
} 


\section{TABLE 3}

The costs of natural disasters and GDP per capita

\begin{tabular}{|c|c|c|c|c|c|c|}
\hline \multirow[b]{2}{*}{ Dependent Variable: } & \multicolumn{3}{|c|}{$\begin{array}{l}\text { Earthquakes } \\
\text { (Richter Scale) }\end{array}$} & \multicolumn{3}{|c|}{$\begin{array}{l}\text { Storms and Hurricanes } \\
\text { (Wind Speed) }\end{array}$} \\
\hline & $\begin{array}{l}\text { Killed } \\
(\log )\end{array}$ & $\begin{array}{l}\text { Affected } \\
\text { (log) }\end{array}$ & $\begin{array}{l}\text { Damage } \\
\text { (log) }\end{array}$ & $\begin{array}{c}\text { Killed } \\
(\log )\end{array}$ & $\begin{array}{l}\text { Affected } \\
\text { (log) }\end{array}$ & $\begin{array}{l}\text { Damage } \\
\text { (log) }\end{array}$ \\
\hline & (1) & (2) & (3) & (4) & (5) & (6) \\
\hline Disaster intensity & $\begin{array}{c}0.827^{* * *} \\
(0.13)\end{array}$ & $\begin{array}{c}0.827^{* * *} \\
(0.13)\end{array}$ & $\begin{array}{c}0.623^{* * *} \\
(0.15)\end{array}$ & $\begin{array}{c}0.015^{* * *} \\
(0.00)\end{array}$ & $\begin{array}{c}0.034^{* * *} \\
(0.00)\end{array}$ & $\begin{array}{c}0.031^{* * *} \\
(0.00)\end{array}$ \\
\hline GDP per capita (log) & $\begin{array}{l}0.003 \\
(0.18)\end{array}$ & $\begin{array}{c}-0.286^{*} \\
(0.17)\end{array}$ & $\begin{array}{c}1.132^{* * *} \\
(0.25)\end{array}$ & $\begin{array}{c}-0.323^{* * *} \\
(0.06)\end{array}$ & $\begin{array}{c}-0.452^{* * *} \\
(0.11)\end{array}$ & $\begin{array}{c}0.293^{* *} \\
(0.14)\end{array}$ \\
\hline Observations & 472 & 641 & 268 & 1,332 & 1,157 & 929 \\
\hline Adjusted $R^{2}$ & 0.106 & 0.177 & 0.245 & 0.342 & 0.297 & 0.323 \\
\hline
\end{tabular}

Note: ${ }^{* * *},{ }^{* *},{ }^{*}$ denote significance at the $1 \%, 5 \%$, and $10 \%$ level, respectively. Robust standard errors reported in parentheses. Controls and time fixed effects included but not reported. Controls include the log of total population and land area, $\%$ of land area in tropics, Chinn-Ito financial openness, Sachs-Warner trade openness. Matched eventbased database (EM-DAT and GeoMet), covering years 1979 to 2010.

human damage (from EM-DAT) on the physical intensity measure of natural disasters (from GeoMet) and characteristics of the countries, in which the disasters occurred. The table shows only the elasticity of GDP per capita, but the regressions also contain a host of other controls (such as geographical variables or measures of openness, and a full array of year dummies) ${ }^{20}$ To save space, we focus on earthquakes and storms; other disaster types reveal similar patterns. The regressions show that moving up the Richter scale by one point increases the human toll by about $83 \%$ while monetary damage increases by $62 \%$. Increasing the wind speed of a storm by 10 knots results in an increase of $15 \%$ in the number of killed, of $34 \%$ in the number of affected, and of $31 \%$ in the monetary damage. Moreover, the partial correlation of GDP per capita with the human costs of disasters is negative, while that with the monetary costs is positive. Disasters in

\footnotetext{
${ }^{20}$ We measure openness with the Chinn-Ito index, which reports the degree of capital account openness of a country, the Sachs-Warner trade policy openness measure - The measure classifies an economy as open if: (i) its average tariff rate was below $40 \%$, (ii) its non-tariff barriers covered less than $40 \%$ of imports, (iii) it had no socialist economic system (iv) it had no state monopoly of major exports, or (v) its blackmarket premium was under 20\% during either the 1970s or the 1980s; see Sachs and Warner (1995) and for an update Wacziarg and Welch (2008) - or the UN General Assembly roll-call vote correlation of countries with G8 powers (Data on the United Nations General Assembly voting stem from Erik Voeten's homepage http://dvn.iq.harvard.edu/dvn/dv/Voeten).
} 
developed countries destroy more physical capital but less human capital. This finding suggests that it is risky to use outcome-based disaster information (as from EM-DAT) in growth regressions, since the reported damage is positively correlated with GDP per capita, the dependent variable in those frameworks.

FIGURE 1

The number of natural disasters over time
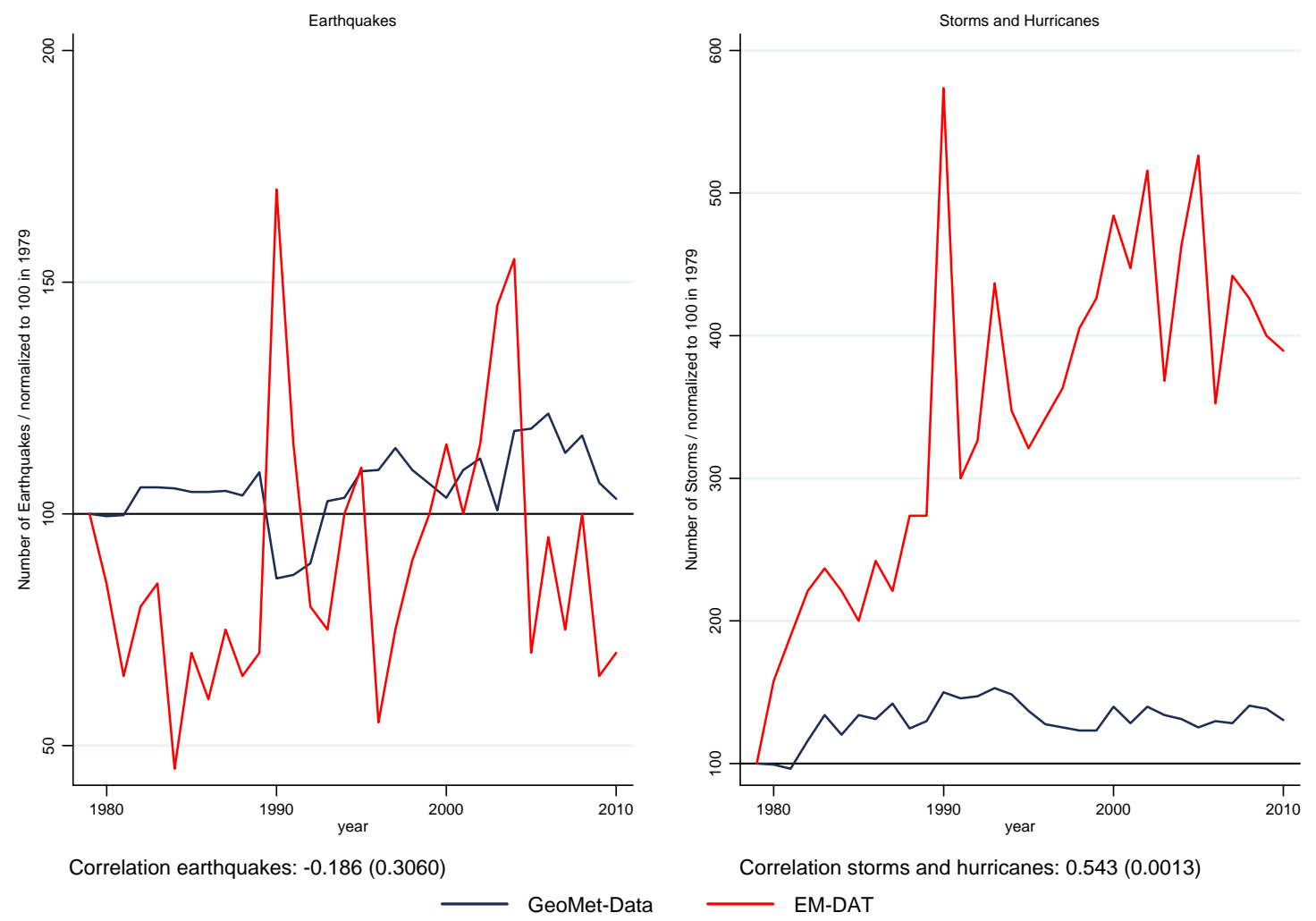

Note: Matched event-based dataset (EM-DAT + GeoMet). The number of disasters are normalized to 100 in 1979. We use earthquakes of Richter scale 4 an higher, and storms and hurricanes with a wind speed of 64 and higher, which equals hurricanes of scale 1 and larger, to catch sufficiently large events. For EM-DAT, we use all reported disaster events, entries into the database already fulfill certain criteria to be recorded as a disaster event.

Finally, we turn to the time dimension. The left-hand plot in Figure 1 shows the yearly number of large earthquake events from EM-DAT against an equivalent number from our GeoMet data, normalizing the initial level (1979) to 100. Regardless of the database, the two series do not exhibit any time trend, but EM-DAT data are much more volatile. Interestingly, there is no statistically significant correlation between the 
two series. The right-hand plot reports storms and hurricanes. Both the Geo-Met data and the EM-DAT data exhibit upward trends, presumably due to climate change, but less in GeoMet (where there is no discernible trend after 1990 anymore) than in EMDAT. The correlation for storms and hurricanes between EM-DAT and GeoMet is high (0.632). As before, the EM-DAT data are more volatile than the GeoMet data. ${ }^{21}$.

\subsection{Disaster Reporting and GDP Per Capita}

A major problem with the existing disasters data bases is that they do not include the universe of events and that selection may not be random. In particular, it is possible that events in countries with certain characteristics such as higher insurance penetration are more likely to be present in the data, and that these characteristics correlate with the variable of interest in cross-country income regressions: GDP per capita. To check this possibility, we estimate the probability of a disaster being reported in EMDAT using a linear probability model

$$
\text { Report }_{k, i, t}=\beta_{1} \text { Intensity }_{k, i, t}+\boldsymbol{\beta}_{\mathbf{5}} \boldsymbol{X}_{i, t}+\nu_{i}+\nu_{t}+\varepsilon_{k, i, t}
$$

where, Report Ri,it $_{\text {is }}$ is one if a specific disaster event $k$ is reported in a specific country $i$ at time $t$ in EM-DAT, and zero otherwise. ${ }^{22}$ Intensity ${ }_{k, i, t}$ is the maximum Richter scale value matched to EM-DAT for earthquakes, the maximum wind speed for storms, the maximum VEI reported for volcanic eruptions, the maximum difference in monthly precipitation in $\mathrm{mm}$ reported for drought or flooding events, and the maximum absolute difference in monthly temperature in ${ }^{\circ} \mathrm{C}$ reported for extreme temperature events. Vector $\boldsymbol{X}_{\boldsymbol{i}, t}$ contains time-varying controls, such as the logarithm of total population (taken from the Penn World Tables (PWT, 7.1)), an index for democratic orientation, ${ }^{23}$ and five bins for GDP per capita corresponding to the 1-20th, 21-40th, 41-60th, 61-80th,

\footnotetext{
${ }^{21}$ Figure 1 tells nothing about whether disaster have become stronger over time. Comparing kernel densities of disaster intensities from 1990-2000 and 2000-2010 for earthquakes and storms, we find that earthquakes have not become stronger over time, while storms have now less mass in the middle of the distribution indicating that not necessarily more storms or hurricanes take place, but those that happen are stronger and thus more destructive (compare Figures B-II and B-III in the Web Appendix)

${ }^{22}$ See Kahn (2005).

${ }^{23}$ We use the polity index from the Polity IV Project. The polity index is rescaled and normalized between 0 and 1 , with 0 being the most autocratic state and 1 being the most democratic nation.
} 
an 81-100th percentiles of the world per capita income distribution. ${ }^{24}$ To control for time-invariant country specific characteristics, we include country fixed effects. Time fixed effects control for time trends common to all disaster events. ${ }^{25}$

TABLE 4

Reporting probability in EM-DAT (1979-2010)

\begin{tabular}{|c|c|c|c|c|c|c|}
\hline \multirow[t]{2}{*}{ Dependent Variable: } & \multicolumn{6}{|c|}{ Variable equals one if disaster is reported in EM-DAT } \\
\hline & $\begin{array}{c}\text { Earthquakes } \\
\text { (1) }\end{array}$ & $\begin{array}{c}\text { Volcano } \\
\text { (2) }\end{array}$ & $\begin{array}{c}\text { Storms } \\
\text { (3) }\end{array}$ & $\begin{array}{c}\text { Floods } \\
\text { (4) }\end{array}$ & $\begin{array}{c}\text { Droughts } \\
\text { (5) }\end{array}$ & $\begin{array}{c}\text { Extreme } \\
\text { Temperature } \\
\text { (6) }\end{array}$ \\
\hline Richter scale & $\begin{array}{c}0.051^{* * *} \\
(0.00)\end{array}$ & & & & & \\
\hline Volcanic Explosivity Index & & $\begin{array}{c}0.099 * * * \\
(0.02)\end{array}$ & & & & \\
\hline Wind speed & & & $\begin{array}{c}0.002^{* * *} \\
(0.00)\end{array}$ & & & \\
\hline$\Delta$ precipitation & & & & $\begin{array}{c}0.031^{* * *} \\
(0.00)\end{array}$ & $\begin{array}{c}0.002^{*} \\
(0.00)\end{array}$ & \\
\hline$\Delta$ temperature & & & & & & $\begin{array}{c}0.001^{* *} \\
(0.00)\end{array}$ \\
\hline In GDP per capita & & & & & & \\
\hline 2nd quintile & $\begin{array}{c}0.018^{*} \\
(0.01)\end{array}$ & $\begin{array}{l}-0.298 \\
(0.24)\end{array}$ & $\begin{array}{c}0.016^{* * *} \\
(0.01)\end{array}$ & $\begin{array}{c}0.012^{* *} \\
(0.01)\end{array}$ & $\begin{array}{l}0.003 \\
(0.00)\end{array}$ & $\begin{array}{l}0.003 \\
(0.00)\end{array}$ \\
\hline 3rd quintile & $\begin{array}{c}0.029^{* *} \\
(0.01)\end{array}$ & $\begin{array}{c}-0.388 \\
(0.24)\end{array}$ & $\begin{array}{l}0.010 \\
(0.01)\end{array}$ & $\begin{array}{c}0.022^{* * *} \\
(0.01)\end{array}$ & $\begin{array}{l}0.004 \\
(0.00)\end{array}$ & $\begin{array}{l}0.001 \\
(0.00)\end{array}$ \\
\hline 4 th quintile & $\begin{array}{c}0.034^{* * *} \\
(0.01)\end{array}$ & $\begin{array}{c}-0.354 \\
(0.25)\end{array}$ & $\begin{array}{c}0.013^{*} \\
(0.01)\end{array}$ & $\begin{array}{c}0.017^{* *} \\
(0.01)\end{array}$ & $\begin{array}{l}0.003 \\
(0.00)\end{array}$ & $\begin{array}{c}-0.001 \\
(0.00)\end{array}$ \\
\hline 5th quintile & $\begin{array}{c}0.036^{* *} \\
(0.01)\end{array}$ & $\begin{array}{c}-0.364 \\
(0.25)\end{array}$ & $\begin{array}{l}0.011 \\
(0.01)\end{array}$ & $\begin{array}{l}0.010 \\
(0.01)\end{array}$ & $\begin{array}{l}0.002 \\
(0.00)\end{array}$ & $\begin{array}{l}0.001 \\
(0.00)\end{array}$ \\
\hline Observations & 27,708 & 870 & 52,866 & 56,760 & 56,760 & 52,473 \\
\hline Adjusted $R^{2}$ & 0.126 & 0.171 & 0.195 & 0.090 & 0.018 & 0.028 \\
\hline
\end{tabular}

Note: ${ }^{* * *}, * *, *$ denote significance at the $1 \%, 5 \%$, and $10 \%$ level, respectively. Country and time fixed effects included but not reported. Controls included but not reported comprise the logarithm of population and an index of democracy. All estimations use a linear probability specification. Matched event-based database (EM-DAT + GeoMet-Data).

Table 4 reports results, suppressing controls for the sake of space. It looks at six

\footnotetext{
${ }^{24}$ These are equivalent to the logarithmic GDP per capita of $[0,6.198),[6.198,7.596),[7.596,8.994)$, [8.994, 10.392), [10.392, max).

${ }^{25}$ Figure B-IV in the Web Appendix plots the distribution of reported disasters of GDP per capita levels. It finds that earthquakes, storms, and heat-waves in rich countries are over represented in the EM-DAT data base relative to GeoMet while the opposite is true with volcanic eruptions, floods and droughts.
} 
types of natural disasters. For all of them, the probability of reporting is higher, the stronger the physical intensity of the disaster. ${ }^{26}$ For instance, an earthquake with an intensity of 8 on the Richter scale has a probability of reporting that is 31 percentage points higher than that of an event with intensity $2 .{ }^{27}$ For earthquakes, storms and floods, we find that GDP per capita is an important predictor for inclusion into EMDAT. For example, an earthquake of given intensity has a reporting probability that is 3.6 percentage points higher in a country belonging to the 5th quintile of the income distribution relative to a country in the poorest category. ${ }^{28}$

So, the conclusion is that insurance-based or news-driven data sets of natural disasters pose important problems: (i) they are subject to selection bias, and (ii) intensity measures are likely correlated with error terms in growth regressions. Our GeoMet data set is better suited for causal inference as it reports physical intensity measures for the universe of geophysical and meteorological events.

\section{The Effect of Natural Disasters on Growth}

\subsection{Empirical Framework}

We are now ready to revisit the effect of natural disasters on per capita income growth using GeoMet data and to compare it with the results obtained with EM-DAT. The unit of observation are country-year combinations, and the disaster variables aggregate over events in a single year. We use a very standard growth regression framework. Following Mankiw et al. (1992), Islam (1995), and most subsequent empirical models on economic performance, we include lagged GDP per capita to estimate a dynamic model. Our basic specification takes the form

$$
\Delta \ln y_{i, t}=(\rho-1) \ln y_{i, t-1}+\alpha \mathbf{D}_{i, t}+\boldsymbol{\beta} \boldsymbol{X}_{\boldsymbol{i , t - 1}}+\nu_{i}+\nu_{t}+\varepsilon_{i, t},
$$

\footnotetext{
${ }^{26}$ Relevant ranges of intensity measures are found in Table 2.

${ }^{27} 100 \times(8-2) \times 0.051$.

${ }^{28}$ When we include further control variables, such openness measures or the UN General Assembly roll-call vote correlation of countries with G8 powers the pattern remains intact. We also find very similar patterns using Munich Re's NatCatSERVICE data; see Tables B-II, and B-III in the Web Appendix. In these tables, we find that more democratic countries report more disasters, while results on openness depend on the disaster type. For instance, the probability of reporting an earthquake decreases with financial openness, but increases with trade policy openness, everything else equal. Results on the correlation of UN votes are mixed.
} 
where $\Delta \ln y_{i, t} \equiv \ln y_{i, t}-\ln y_{i, t-1}$ is the growth rate of real GDP per capita, and $\ln y_{i, t-1}$ is the lagged log of GDP per capita. $D_{i, t}$ is a measure disaster intensity. We either include specific types of disasters happening in a year in a country, or we aggregate different disasters into an overall index. Following related empirical literature, ${ }^{29}$ we work with the unweighted sum of disaster intensity measures and with an alternative definition, which uses the inverse of the standard deviation of a disaster type within a country over all years as precision weights. The latter approach makes sure that no single disaster component dominates the movement of the disaster index. Moreover, as the impact of a given disaster on the economy of a country clearly depends on the disaster intensity relative to the overall size of the country, we follow the literature (i.e., Skidmore and Toya, 2002) and scale all respective disaster variables by land area. To facilitate comparison, we further scale the measures such that they admit the same mean in our sample $(0.041) .30$

The vector of controls $\boldsymbol{X}_{i, t-1}$ contains the variables also used in the related papers of Skidmore and Toya (2002); Noy (2009) and Loayza et al. (2012). These authors use a set of structural, domestic policy, and external factors. Structural factors include a variable of the size of the economy (total population), an index of democratization (polity index), and a measures of openness to trade (imports plus exports divided by GDP). Domestic policy variables comprise inflation, domestic credit, gross capital formation, and the current account balance. External factors are foreign direct investment and real interest rates. ${ }^{31}$ See Table A-I in the Appendix for the summary statistics, data sources, and variable descriptions. To mitigate endogeneity concerns (though, admittedly, not solving them), we use the lag of control variables. Time-invariant country characteristics are accounted for by country-specific fixed effects $\nu_{i}$, while year fixed effects $\nu_{t}$ control for common time trends. Our sample includes 108 countries for the years 1979-2010, but with gaps in time coverage.

In our baseline regressions, we do not explicitly deal with the bias that arises from the presence of a lagged endogenous variable on the right-hand-side of the equation

\footnotetext{
${ }^{29}$ The empirical literature on exchange rate crises works with Exchange Market Pressure Indices which also combines different elements; see (Eichengreen et al., 1995).

${ }^{30}$ The unweighted measure has a standard deviation of 0.199 while the weighted one has a standard deviation of 0.209 .

${ }^{31}$ We take information on these variables from the World Development Indicators database of the World Bank.
} 
(Nickell (1981)), since we know that this bias is small in panels with rather long time dimension like ours $T=30$ (Judson and Owen, 1999). We carry out extensive robustness checks later in this Section. Moreover, one may be worried about panel unit roots. In our regressions, we run F-tests on $H_{0}: \rho-1=0$, typically rejecting the presence of unit roots. Further, we conduct Levin-Lin-Chu unit root tests (Levin et al., 2002) on balanced subsamples and, again, reject the presence of unit roots. ${ }^{32}$

For $\alpha_{2}$, we expect to see economic growth to be lower then trend at the year the disasters strikes, as the production capacity of the economy is at least temporarily reduced. This is because the disaster destroys the capital stock of the country or lowers the productivity of assets such as land. Assuming $\rho<1$, in subsequent periods, as capital is replenished, growth may be above trend and slowly returns back to trend. ${ }^{33}$ We use lags to illustrate the time evolution of disaster effects.

\subsection{Baseline Results}

Table 5 shows the results from regressing aggregate disaster indices on per capita growth. ${ }^{34}$ In the Appendix (Table B-IV), we report results based on a much more balanced parsimonious model which delivers very comparable results.

Table 5 contrasts regressions using different disaster measures. In column (1) we use the unweighted sum of physical intensity measures of disasters that happened in a specific country in a specific year as the key independent variable. Column (2) proposes a refined index, in which physical intensity measures of different disaster types have been weighted with their inverse sample standard deviations. Both indices are built using intensity measures divided by the log area of the affected country to account for the fact that given disasters must have very different GDP effects in countries of different geographical extension. To facilitate comparison, we have further rescaled the aggregate indices such that they have the same sample means (0.0041).

For both indices, we find precisely estimated negative coefficients for the effect of disasters on growth. ${ }^{35}$ These results are in contrast to those obtained from the EM-DAT

\footnotetext{
${ }^{32}$ The Levin-Lin-Chu unit root test exploits the time-series, as well as the cross-section dimension. As the bias-adjusted t statistic is significant at the $1 \%$ level, we can thus reject the Null of a unit root.

${ }^{33}$ See Hochrainer (2009) Figure 1 for a graphical illustration of possible effects.

${ }^{34}$ Summary results including the mean and standard deviations, as well as a description of variables are reported in Table A-I in the Appendix.

${ }^{35}$ The negative effects of disasters on income are in line with findings by Noy (2009) and Loayza et al.
} 
TABLE 5

Growth effects of natural disasters (1979-2010)

\begin{tabular}{|c|c|c|c|c|c|c|}
\hline \multirow{3}{*}{$\begin{array}{l}\text { Dependent Variable: } \\
\text { Disaster Variable }\end{array}$} & \multicolumn{6}{|c|}{$\Delta \ln$ GDP per capita $(\mathrm{N}=1,787 ;$ Countries $=108)$} \\
\hline & \multicolumn{2}{|l|}{ GeoMet } & \multicolumn{2}{|l|}{ EM-DAT } & \multicolumn{2}{|c|}{ NatCatSERVICE } \\
\hline & (1) & $(2)$ & (3) & $(4)$ & (5) & $(6)$ \\
\hline GeoMet Disaster Index ${ }_{i, t}$ & $\begin{array}{c}-0.046^{* * *} \\
(0.01)\end{array}$ & & & & & \\
\hline GeoMet Disaster Index ${ }_{i, t}$, weighted & & $\begin{array}{c}-0.063^{* * *} \\
(0.01)\end{array}$ & & & & \\
\hline EMDAT All Disaster $_{i, t}$ & & & $\begin{array}{l}0.230 \\
(0.59)\end{array}$ & & & \\
\hline EMDAT Large Disaster $_{i, t}$ & & & & $\begin{array}{l}-1.966 \\
(2.12)\end{array}$ & & \\
\hline NatCatSERVICE All Disaster $_{i, t}$ & & & & & $\begin{array}{l}0.044 \\
(0.03)\end{array}$ & \\
\hline NatCatSERVICE Large Disaster ${ }_{i, t}$ & & & & & & $\begin{array}{l}-2.626 \\
(3.06)\end{array}$ \\
\hline \multicolumn{7}{|l|}{ Controls } \\
\hline $\ln$ GDP per capita ${ }_{i, t-1}$ & $\begin{array}{c}-0.090^{* * *} \\
(0.02)\end{array}$ & $\begin{array}{c}-0.089^{* * *} \\
(0.02)\end{array}$ & $\begin{array}{c}-0.088^{* * *} \\
(0.02)\end{array}$ & $\begin{array}{c}-0.088^{* * *} \\
(0.02)\end{array}$ & $\begin{array}{c}-0.089^{* * *} \\
(0.02)\end{array}$ & $\begin{array}{c}-0.088^{* * *} \\
(0.02)\end{array}$ \\
\hline $\ln _{\text {population }}, t-1$ & $\begin{array}{c}-0.075^{* *} \\
(0.04)\end{array}$ & $\begin{array}{c}-0.071^{* *} \\
(0.03)\end{array}$ & $\begin{array}{c}-0.069^{* *} \\
(0.03)\end{array}$ & $\begin{array}{c}-0.070^{* *} \\
(0.03)\end{array}$ & $\begin{array}{c}-0.071^{* *} \\
(0.03)\end{array}$ & $\begin{array}{c}-0.070^{* *} \\
(0.03)\end{array}$ \\
\hline Polity index $x_{i, t-1}$ & $\begin{array}{l}0.025 \\
(0.02)\end{array}$ & $\begin{array}{l}0.025 \\
(0.02)\end{array}$ & $\begin{array}{l}0.024 \\
(0.02)\end{array}$ & $\begin{array}{l}0.024 \\
(0.02)\end{array}$ & $\begin{array}{l}0.025 \\
(0.02)\end{array}$ & $\begin{array}{l}0.024 \\
(0.02)\end{array}$ \\
\hline Trade openness $_{i, t-1}$ & $\begin{array}{c}0.038^{* * *} \\
(0.01)\end{array}$ & $\begin{array}{c}0.039^{* * *} \\
(0.01)\end{array}$ & $\begin{array}{c}0.039 * * * \\
(0.01)\end{array}$ & $\begin{array}{c}0.039 * * * \\
(0.01)\end{array}$ & $\begin{array}{c}0.038^{* * *} \\
(0.01)\end{array}$ & $\begin{array}{c}0.039 * * * \\
(0.01)\end{array}$ \\
\hline Interest rate $e_{i, t-1}$ & $\begin{array}{l}0.009 \\
(0.18)\end{array}$ & $\begin{array}{l}0.013 \\
(0.18)\end{array}$ & $\begin{array}{l}0.007 \\
(0.18)\end{array}$ & $\begin{array}{l}0.006 \\
(0.18)\end{array}$ & $\begin{array}{l}0.007 \\
(0.18)\end{array}$ & $\begin{array}{l}0.006 \\
(0.18)\end{array}$ \\
\hline 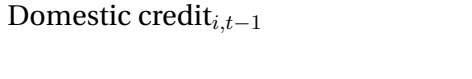 & $\begin{array}{c}-0.036^{* * *} \\
(0.01)\end{array}$ & $\begin{array}{c}-0.036^{* * *} \\
(0.01)\end{array}$ & $\begin{array}{c}-0.036^{* * *} \\
(0.01)\end{array}$ & $\begin{array}{c}-0.036^{* * *} \\
(0.01)\end{array}$ & $\begin{array}{c}-0.036^{* * *} \\
(0.01)\end{array}$ & $\begin{array}{c}-0.036^{* * *} \\
(0.01)\end{array}$ \\
\hline Gross capital formation $_{i, t-1}$ & $\begin{array}{c}0.019^{* *} \\
(0.01)\end{array}$ & $\begin{array}{c}0.019^{* *} \\
(0.01)\end{array}$ & $\begin{array}{c}0.019^{* *} \\
(0.01)\end{array}$ & $\begin{array}{c}0.018^{* *} \\
(0.01)\end{array}$ & $\begin{array}{c}0.019^{* *} \\
(0.01)\end{array}$ & $\begin{array}{c}0.019^{* *} \\
(0.01)\end{array}$ \\
\hline Foreign direct investment $t_{i, t-1}$ & $\begin{array}{l}0.044 \\
(0.05)\end{array}$ & $\begin{array}{l}0.047 \\
(0.05)\end{array}$ & $\begin{array}{l}0.051 \\
(0.05)\end{array}$ & $\begin{array}{l}0.050 \\
(0.05)\end{array}$ & $\begin{array}{l}0.051 \\
(0.05)\end{array}$ & $\begin{array}{l}0.050 \\
(0.05)\end{array}$ \\
\hline $\ln _{\text {Inflation }}, t-1$ & $\begin{array}{c}-0.003^{*} \\
(0.00)\end{array}$ & $\begin{array}{c}-0.003^{*} \\
(0.00)\end{array}$ & $\begin{array}{c}-0.003^{*} \\
(0.00)\end{array}$ & $\begin{array}{c}-0.003^{*} \\
(0.00)\end{array}$ & $\begin{array}{c}-0.003^{*} \\
(0.00)\end{array}$ & $\begin{array}{c}-0.003^{*} \\
(0.00)\end{array}$ \\
\hline Current account balance $_{i, t-1}$ & $\begin{array}{l}0.050 \\
(0.04)\end{array}$ & $\begin{array}{l}0.054 \\
(0.04)\end{array}$ & $\begin{array}{l}0.056 \\
(0.04)\end{array}$ & $\begin{array}{l}0.056 \\
(0.04)\end{array}$ & $\begin{array}{l}0.055 \\
(0.04)\end{array}$ & $\begin{array}{l}0.056 \\
(0.04)\end{array}$ \\
\hline Adjusted $R^{2}$ & 0.242 & 0.243 & 0.241 & 0.242 & 0.242 & 0.242 \\
\hline $\begin{array}{l}\text { Note: }{ }^{* * *},{ }^{* *},{ }^{*} \text { denote significance } \\
\text { effects included but not reported. Ro } \\
108 \text { countries. Column (1) uses the si } \\
\text { measure weighted by the inverse of } t \\
\text { The decision rule for large-scale dis } \\
\text { 'great natural disasters' by Munich } \\
1,000 \text { or more were killed, or (ii) at le } \\
\text { using the deflator on US dollars from }\end{array}$ & $\begin{array}{l}\text { at the } 1 \%, \\
\text { obust stand } \\
\text { imple disast } \\
\text { he within cc } \\
\text { asters from } \\
\text { Re (2006) ar } \\
\text { ast } 1 \text { billion } \\
\text { WDI), and }\end{array}$ & $\begin{array}{l}5 \% \text {, and } 10 \\
\text { ard errors } \mathrm{r} \\
\text { ter index } \mathrm{m} \\
\text { ountry stan } \\
\text { EM-DAT a } \\
\text { ad the Unit } \\
\text { US dollar } \mathrm{r} \\
\text { with EM-D }\end{array}$ & $\begin{array}{l}\text { \% level, re } \\
\text { ported in } p \\
\text { asure, whil } \\
\text { dard deviat } \\
\text { d NatCatS } \\
\text { d Nations. } \\
\text { lonetary d. } \\
\text { AT also if ( }\end{array}$ & $\begin{array}{l}\text { pectively. } \\
\text { arenthesis. } \\
\text { e column (2 } \\
\text { ion of each } \\
\text { ERVICE bas } \\
\text { Disasters } \\
\text { mage (mac } \\
\text { ii) } 100,000\end{array}$ & $\begin{array}{l}\text { Country al } \\
\text { Unbalanc } \\
\text { ) uses the c } \\
\text { respective } \\
\text { es on the c } \\
\text { re defined } \\
\text { e compara } \\
\text { r more aff }\end{array}$ & $\begin{array}{l}\text { time fixed } \\
\text { panel with } \\
\text { aster index } \\
\text { saster type. } \\
\text { nvention of } \\
\text { s large if (i) } \\
\text { le over time } \\
\text { ted. }\end{array}$ \\
\hline
\end{tabular}

(2012). 
or NatCatSERVICE. Columns (3) and (4) are based on the EM-DAT database; columns (5) and (6) are based on the similar NatCatSERVICE data from Munich Re. In both cases, we use the sum of all disasters (columns (3) and (5)) or of large disasters only (columns (4) or (6)). We do not find any evidence that disasters reduce growth on impact; the signs are positive if the index is based on all reported disasters. It turns negative if one uses large disasters only, but standard errors are big and point estimates implausibly large. ${ }^{36}$ Since the disaster measures used in columns (3) to (6) are likely to be positively correlated with the error terms in equation (2), as shown in Section 2.2., we would expect an upward bias in the estimates; this is indeed what we observe in Table 5.

To obtain a quantitative interpretation of these estimates, we evaluate the marginal growth effects at disaster indices of different intensity. In a year, in which the (simple) disaster index is equal to the sample mean of 0.041 , growth is lower by about 0.18 percentage points; a one standard deviation increase of the index above the mean yields a growth penalty of 1.10 points. Similarly, using the weighted index, a year in which the index is equal to the mean, the model predicts that growth is lower by 0.26 percentage points, while a one standard deviation increase above the mean triggers a sizeable growth cut of 1.51 points. Figures 2 evaluates the growth effects of natural disasters at different realizations of the (weighted) disaster index. ${ }^{37}$ The figure implies that the $75 \%$ smallest realizations of the disaster index imply at most a very modest growth effect of $0.1 \%$, much less than the mean effect. Even the $95 \%$ weakest disaster years come with a GDP loss of at most $0.44 \%$. The $1 \%$ worst realizations of the index, however, imply a very substantial growth penalty of $6.9 \%$ (not shown in the figure). This reflects the very skewed distribution of the index and implies that substantial growth effects are to be expected only from the very worst disaster years.

Tables B-IV and B-V in the Web Appendix provide robustness checks to Table 5. In the first case, we use a very parsimonious model in which growth is regressed only on the lagged level of GDP per capita and on our disaster measures. In the second case, we work with a first-difference the model rather than use the within transformation to partial out unobserved heterogeneity. In both cases, the indices based on GeoMet produce significant, negative effects of disasters on growth while the alternative measures

\footnotetext{
${ }^{36}$ The lagged endogenous variable and other controls give very similar point estimates across all models, with sign and significance patterns in line with the literature.

${ }^{37}$ The picture is qualitatively and quantitatively very similar if the unweighted index is used.
} 
FIGURE 2

Growth effects of natural disasters as a function of disaster intensity

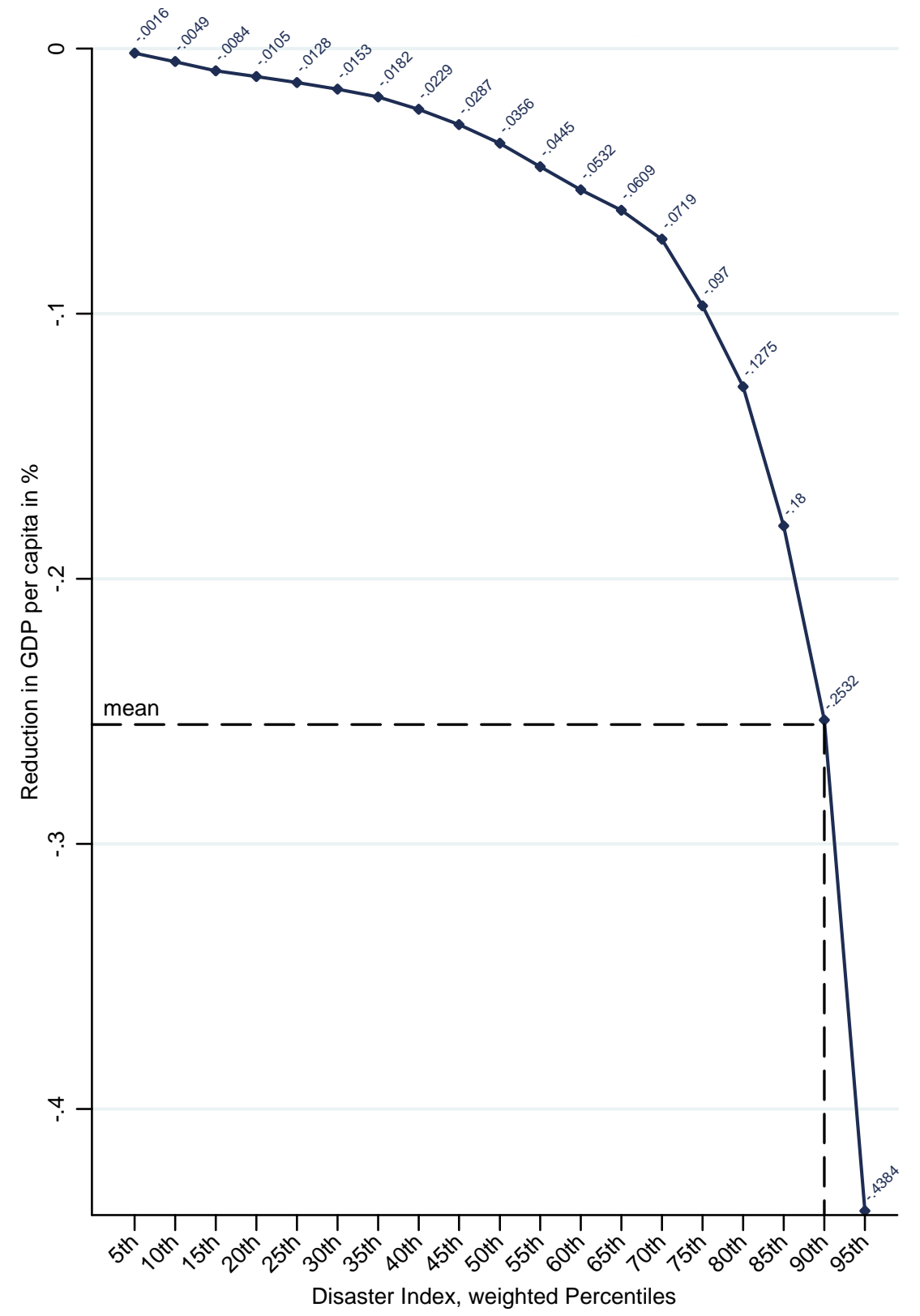

Note: The Figure plots the estimated GDP growth effects loss of disasters on GDP per capita in \% as a function of different realizations of the weighted disaster index. Estimates as of Table B-IV column (2).

do not yield statistically significant results. Table B-VI reports results from a specification that regresses the log level of GDP per capita on natural disasters and the other 
controls used in Table 5 (including country and year dummies) but does not include the lagged value of the dependent variable on the right-hand-side. Earlier results are confirmed.

\subsection{Effects by Type of Disaster}

Next, we replace the summary disaster measures of Table 5 with the disaggregated disaster intensity measures for earthquakes, volcano eruptions, storms, floods, droughts, and extreme temperature. We aggregate events within a year by selecting the maximum intensity measure reported for that year. All intensity measures are scaled by the land area of the country in which they have occurred. To enable easy comparison across disaster types, we have further rescaled the variables such that they all have the same sample mean (0.009). ${ }^{38}$ Otherwise, we keep the empirical strategy used above.

\section{TABLE 6}

Growth effects of natural disasters by type of disaster (1979-2010)

Dependent Variable: $\Delta \ln$ GDP per capita

\begin{tabular}{|c|c|c|c|c|c|c|c|}
\hline & (1) & (2) & (3) & (4) & (5) & (6) & (7) \\
\hline Richter scale $_{i, t}$ & $\begin{array}{c}-0.270^{* * *} \\
(0.08)\end{array}$ & & & & & & $\begin{array}{c}-0.177^{* * *} \\
(0.06)\end{array}$ \\
\hline $\mathrm{VEI}_{i, t}$ & & $\begin{array}{c}0.029^{* *} \\
(0.01)\end{array}$ & & & & & $\begin{array}{c}0.029^{* *} \\
(0.01)\end{array}$ \\
\hline Wind speed $_{i, t}$ & & & $\begin{array}{c}-0.181^{* * *} \\
(0.07)\end{array}$ & & & & $\begin{array}{c}-0.177^{* * *} \\
(0.06)\end{array}$ \\
\hline Positive $\Delta \operatorname{rain}_{i, t}$ & & & & $\begin{array}{c}-0.024^{*} \\
(0.01)\end{array}$ & & & $\begin{array}{c}-0.020 \\
(0.02)\end{array}$ \\
\hline Drought $_{i, t}$ (dummy) & & & & & $\begin{array}{c}-0.013^{* * *} \\
(0.00)\end{array}$ & & $\begin{array}{c}-0.013^{* * *} \\
(0.00)\end{array}$ \\
\hline$\Delta$ temperature $_{i, t}$ & & & & & & $\begin{array}{c}-0.045^{* *} \\
(0.02)\end{array}$ & $\begin{array}{c}-0.052^{* * *} \\
(0.02)\end{array}$ \\
\hline Adjusted $R^{2}$ & 0.242 & 0.242 & 0.242 & 0.241 & 0.242 & 0.242 & 0.242 \\
\hline
\end{tabular}

Note: ${ }^{* * *},{ }^{* *},{ }^{*}$ denote significance at the $1 \%, 5 \%$, and $10 \%$ level, respectively. Robust standard errors reported in parentheses. Controls, country and time fixed effects included but not reported. Controls are included as of Table 5 column (1). $N=1,787,108$ countries.

Drawing on our GeoMet data, Table 6 reports results (suppressing, for brevity, the

\footnotetext{
${ }^{38}$ See Table A-I in the Appendix for standard deviations.
} 
coefficients of further controls). We first introduce disaster types separately in columns (1) to (6), and then jointly in column (7). All disaster types have a statistically significant effect on growth if entered separately into the regression. All types reduce growth with volcano eruptions being the sole exception. Note, however, that volcano eruptions are rare events in our database, and that they are geographically fixed, occurring only in a few countries. In the presence of country fixed effects, this impairs clean identification. ${ }^{39}$ The coefficients of control variables are almost exactly the same as in Table 5.

Multiplying the estimated coefficient by 0.009 (the sample average of all disaster types), one obtains the quantitative growth effect of an average natural disaster. An average earthquake reduces growth on impact by 0.16 , an average storm by 0.16 , an average drought by 0.01 , and an average extreme temperature event by 0.05 percentage points. The five percent strongest events reduce GDP per capita by at least -2.32 percentage points for earthquakes, $-1.75,-0.34$ and -0.09 percentage points for storms, droughts, and extreme temperature events, respectively. ${ }^{40}$ Not surprisingly, earthquakes and storms have stronger effects, since they affect larger portions of the economy. Droughts and extreme weather events are mostly relevant for the agricultural sector only.

It is interesting, to evaluate the estimates in 6 with the data of a few famous disaster events. In August 2005, hurricane Katrina devastated the US Gulf Coast. The monetary damage of the disaster, as reported in EM-DAT, amounted to about 125 billion US dollar or $0.01 \%$ of US GDP from that year. Evaluating column (3) with the specific data from that event, we find that Katrina reduced GDP per capita by $0.002 \%$ in 2005 . This is a small number which reflects the large size of the overall US economy relative to the size of the affected region. Yet, the magnitude is plausible, since it corresponds to an output elasticity of capital of about $0.2 .^{41}$

The winter storms Lothar and Martin affected Europe in 1999. They caused a mon-

\footnotetext{
${ }^{39}$ Table B-IX in the Web Appendix uses the smaller country sample suggested by Mankiw et al. (1992). This sample excludes countries for which oil-production was the dominant industry and states that formerly were part of the Soviet Union or Soviet satellite states and is well established in the growth literature (e.g., Islam, 1995; Caselli et al., 1996; Klenow and Rodriguez-Clare, 1997; Felbermayr and Gröschl, 2013). We find very similar results in this sample.

${ }^{40}$ In these calculations, we assume that disaster events are approximately normally distributed.

${ }^{41}$ We may use $\Delta \% y=\kappa \Delta \% K$, where $\Delta \% y$ is the percentage change in per capita output (GDP), $\Delta \% K$ is the change in the stock of physical capital, and $\kappa$ is the output elasticity of the capital stock in a neoclassical production function (often estimated between 0.2 and 0.4 in OECD countries).
} 
etary damage of about 2.6 billion US dollar in Denmark. This corresponds to approximately $0.86 \%$ of GDP. According to our estimates, the GDP per capita drop in Denmark was $0.27 \%$; this suggests an output elasticity of capital of about 0.3 . On January 22010 , Haiti suffered an earthquake with an intensity of 7.8 on the Richter scale. According to EM-DAT it resulted in a damage of 8 billion US dollar or $0.56 \%$ if GDP. In our empirical model, the disaster caused a reduction in real GDP per capita by $0.05 \%$, possibly reflecting the low capital intensity of production in a very poor country such as Haiti.

Droughts can cause substantial GDP losses as well. In 1983, a strong drought generated a loss in GDP per capita of $0.16 \%$ in Syria; in Guatemala a drought generated a loss of $0.27 \%$ of GDP in 1998. The heat wave that hit Europe in the year 2006 reduced GDP per capita in several countries with the largest loss in Hungary (0.37\%). The 2007 heat wave in Southeast Asia caused a loss of GDP per capita of $0.02 \%$ in China and of $0.52 \%$ in Vietnam.

\subsection{Further Results Checks}

Heterogeneity across Samples. We start by exploring the impact of natural disasters on the economic activity of various country groups. Table 7 summarizes results. All regressions include the full set of control variables, country and time fixed effects. First, we separate developing from industrialized economies in columns (1) and (2). In Panel A, we find that both, non-OECD and OECD countries are negatively affected by natural disasters. This finding is revised in Panel B, where we use the weighted disaster index measure. We find that only developing countries experience a negative effect, while the effect on industrialized countries turns insignificant. In Panel C, we find that larger earthquakes, storms, and temperature extremes negatively affect per capita income in non-OECD countries in column (1). For OECD economies, solely storms and droughts exert a negative effect in column (2).

Columns (3) to (4) decompose the sample into low and middle, and high income countries according to the convention of the World Bank. Results show that low and middle income countries suffer from natural disasters; see Panel A column (3). The effect is reversed in Panel B column (4), where we find a negative impact only for high income countries. It appears that droughts and storms hurt GDP per capita in high income countries (Panel C column (4)), while earthquakes or storms have more adverse 
TABLE 7

Growth effects of natural disasters by sample (1979-2010)

\begin{tabular}{|c|c|c|c|c|c|c|}
\hline \multirow{2}{*}{$\begin{array}{l}\text { Dependent Variable: } \\
\text { Sample: }\end{array}$} & \multicolumn{6}{|c|}{$\Delta \ln$ GDP per capita } \\
\hline & $\begin{array}{c}\text { Non- } \\
\text { OECD } \\
(1) \\
\end{array}$ & $\begin{array}{l}\text { OECD } \\
(2)\end{array}$ & $\begin{array}{l}\text { Low/Middle } \\
\text { Income } \\
\text { (3) }\end{array}$ & $\begin{array}{c}\text { High } \\
\text { Income } \\
(4)\end{array}$ & $\begin{array}{c}\text { Democracy } \\
\text { (5) }\end{array}$ & $\begin{array}{c}\text { Autocracy } \\
\text { (6) }\end{array}$ \\
\hline \multicolumn{7}{|c|}{ PANEL A: Disaster Index } \\
\hline Disaster index ${ }_{i, t}$ & $\begin{array}{c}-0.059^{* * *} \\
(0.02)\end{array}$ & $\begin{array}{c}-0.412^{*} \\
(0.23)\end{array}$ & $\begin{array}{c}-1.178^{*} \\
(0.66)\end{array}$ & $\begin{array}{l}-0.010 \\
(0.02)\end{array}$ & $\begin{array}{l}-0.015 \\
(0.11)\end{array}$ & $\begin{array}{c}-0.059^{*} \\
(0.03)\end{array}$ \\
\hline Observations & 1,282 & 505 & 1,165 & 622 & 1,355 & 432 \\
\hline Adjusted $R^{2}$ & 0.247 & 0.542 & 0.238 & 0.418 & 0.324 & 0.157 \\
\hline \multicolumn{7}{|c|}{ PANEL B: Disaster Index, weighted } \\
\hline Disaster index, weighted $_{i, t}$ & $\begin{array}{c}-0.068^{* * *} \\
(0.01)\end{array}$ & $\begin{array}{c}-0.155 \\
(0.36)\end{array}$ & $\begin{array}{r}-1.245 \\
(0.99)\end{array}$ & $\begin{array}{c}-0.043^{* * *} \\
(0.01)\end{array}$ & $\begin{array}{r}-0.033 \\
(0.08)\end{array}$ & $\begin{array}{c}-0.066^{* *} \\
(0.03)\end{array}$ \\
\hline Observations & 1,282 & 505 & 1,165 & 622 & 1,355 & 432 \\
\hline Adjusted $R^{2}$ & 0.247 & 0.541 & 0.234 & 0.421 & 0.324 & 0.156 \\
\hline \multicolumn{7}{|c|}{ PANEL C: Disaster Intensity Measures } \\
\hline Richter scale $_{i, t}$ & $\begin{array}{c}-0.189 * * \\
(0.07)\end{array}$ & $\begin{array}{l}2.076 \\
(7.48)\end{array}$ & $\begin{array}{c}-20.190^{*} \\
(11.47)\end{array}$ & $\begin{array}{r}-0.091 \\
(0.08)\end{array}$ & $\begin{array}{l}-0.291 \\
(1.73)\end{array}$ & $\begin{array}{l}-0.221 \\
(0.22)\end{array}$ \\
\hline $\mathrm{VEI}_{i, t}$ & $\begin{array}{c}0.025^{*} \\
(0.01)\end{array}$ & $\begin{array}{l}0.051 \\
(0.05)\end{array}$ & $\begin{array}{c}0.040^{* *} \\
(0.02)\end{array}$ & $\begin{array}{l}0.039 \\
(0.05)\end{array}$ & $\begin{array}{l}0.027^{*} \\
(0.01)\end{array}$ & $\begin{array}{r}-0.007 \\
(0.24)\end{array}$ \\
\hline Wind speed $_{i, t}$ & $\begin{array}{c}-0.244^{* * *} \\
(0.07)\end{array}$ & $\begin{array}{c}-1.823^{*} \\
(0.89)\end{array}$ & $\begin{array}{c}-4.644^{*} \\
(2.53)\end{array}$ & $\begin{array}{l}-0.033 \\
(0.08)\end{array}$ & $\begin{array}{r}-0.099 \\
(0.41)\end{array}$ & $\begin{array}{c}-0.250^{* *} \\
(0.11)\end{array}$ \\
\hline Positive $\Delta \operatorname{rain}_{i, t}$ & $\begin{array}{l}-0.021 \\
(0.02)\end{array}$ & $\begin{array}{l}-0.176 \\
(0.46)\end{array}$ & $\begin{array}{l}0.031 \\
(0.76)\end{array}$ & $\begin{array}{r}-0.008 \\
(0.01)\end{array}$ & $\begin{array}{c}-0.294^{* * *} \\
(0.11)\end{array}$ & $\begin{array}{r}-0.010 \\
(0.01)\end{array}$ \\
\hline Drought $_{i, t}$ (dummy) & $\begin{array}{c}-0.008 \\
(0.01)\end{array}$ & $\begin{array}{c}-0.097^{* * *} \\
(0.02)\end{array}$ & $\begin{array}{l}0.063 \\
(0.05)\end{array}$ & $\begin{array}{c}-0.017^{* *} \\
(0.01)\end{array}$ & $\begin{array}{c}-0.011^{* *} \\
(0.00)\end{array}$ & $\begin{array}{c}-0.048^{* * *} \\
(0.01)\end{array}$ \\
\hline$\Delta$ temperature $_{i, t}$ & $\begin{array}{c}-0.070^{* * *} \\
(0.02)\end{array}$ & $\begin{array}{l}0.014 \\
(0.04)\end{array}$ & $\begin{array}{c}-0.034 \\
(0.03)\end{array}$ & $\begin{array}{c}-0.047^{* *} \\
(0.02)\end{array}$ & $\begin{array}{c}-0.031 \\
(0.02)\end{array}$ & $\begin{array}{c}-0.100^{*} \\
(0.06)\end{array}$ \\
\hline Observations & 1,282 & 505 & 1,165 & 622 & 1,355 & 432 \\
\hline Adjusted $R^{2}$ & 0.246 & 0.539 & 0.238 & 0.421 & 0.324 & 0.150 \\
\hline
\end{tabular}

Note: ${ }^{* * *},{ }^{* *}, *$ denote significance at the $1 \%, 5 \%$, and $10 \%$ level, respectively. Standard errors reported in parenthesis. Controls, country and time fixed effects included but not reported. Controls included as of Table 6 column (6). Columns (3) to (5) use the classification of income groups of the World Bank. Column (6) includes countries with a polity index above 0.5 , while column (7) includes those with a polity index below or equal to 0.5 .

effects on economic activity in low and middle income countries; see Panel C column (3). 
Finally, in columns (5) and (6), we distinguish between democratic countries (polity index $>0.5$ ) and autocracies (polity index<=0.5). Findings suggest that democratic countries can better cope with natural disasters than autocracies. While democratic nations' income per capita suffers, on average, most from the adverse effect of too much rain (floods) or too little rain (droughts) (Panel C column (5)), per capita GDP in autocratic nations is mainly reduced due to storms, droughts, and extreme temperature events (Panel C column (7)). Summarizing, high income (democratic) countries are more likely affected by meteorological and poorer countries by geophysical events.

Lagged effects of disasters. The neoclassical growth model predicts that disasters lower GDP per capita on impact, i.e., their growth effect is negative in the very short run. After the disaster, growth is temporarily higher than on the balanced growth back due to the concavity of the aggregate production function (i.e., empirically, because the lagged level of GDP in the regressions has a negative sign). So far, our results are perfectly compatible with this view. However, some observers believe that the forced replacement of the capital stock may temporarily increase the growth rate of total factor productivity as newer capital goods are more efficient than once installed at earlier times (Caballero and Hammour, 1994). Hence, in subsequent periods following the disaster growth may be boosted by more than what the neoclassical model would suggest. To capture this idea, we add five yearly lags of the disaster variables into our growth regressions.

Figure 3 illustrates the findings. ${ }^{42}$ Putting aside the case of volcano eruptions, for which we have found positive effects before, all panels in the Figure show negative impact effects which are, however, not always statistically significant. In some cases, we report positive and statistically significant effects of past disasters on growth. However, the sum of significant coefficients results in a negative value for all cases. In the case of the aggregate indices (unweighted and weighted), we find a sum of -0.098 and -0.071 , respectively, which amounts to a more negative effect than the one obtained in Table 5 (-0.046 and -0.063 , respectively). So, disasters have direct effects on GDP per capita in the years subsequent to their occurrence, but these effects are negative. This is most visible in the case of earthquakes, where the sum of contemporaneous and lagged ef-

\footnotetext{
${ }^{42}$ Table B-X in the Web Appendix reports detailed results.
} 
FIGURE 3

The growth effect of disasters over time
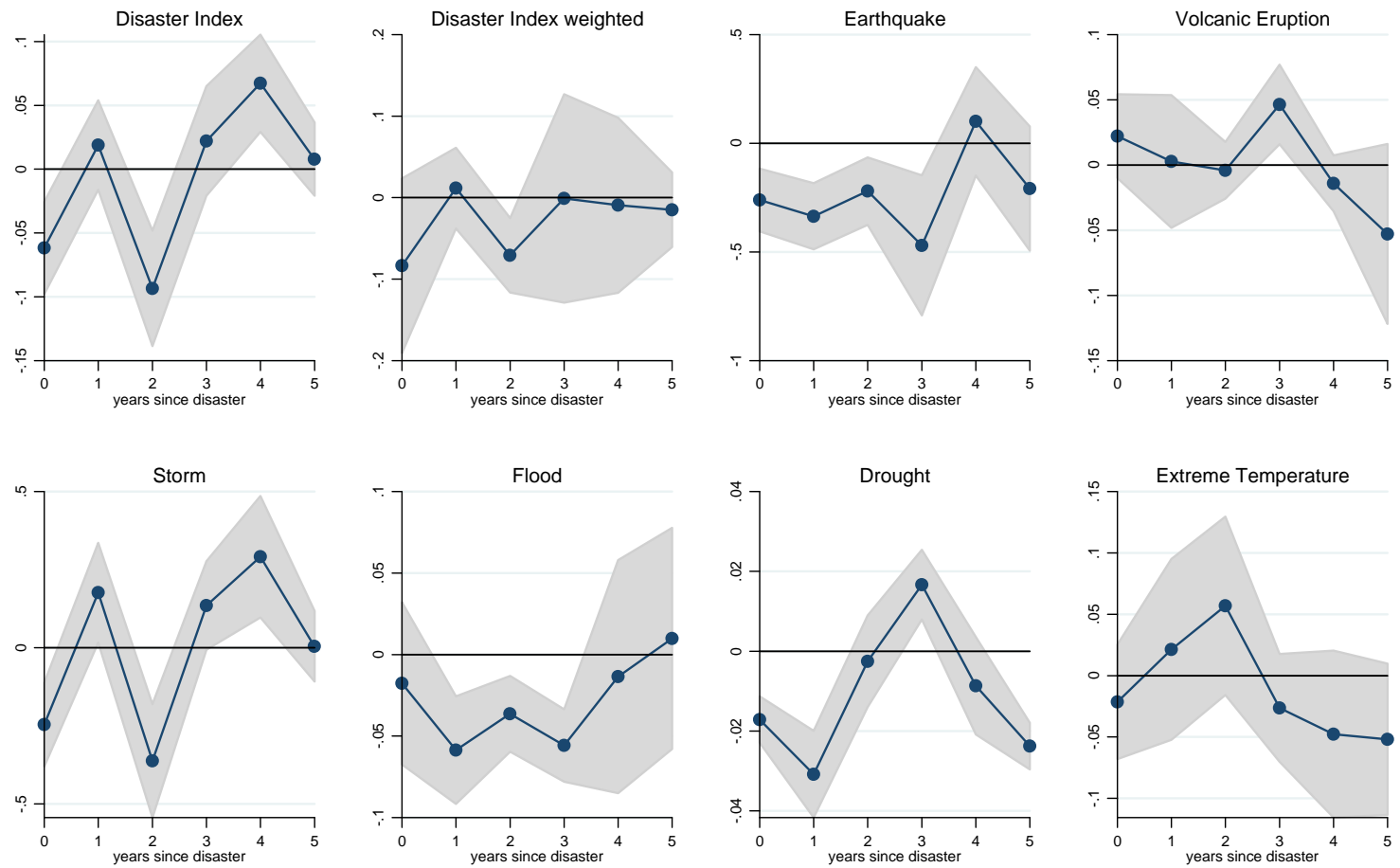

Upper 95\% confidence limit/Lower 95\% confidence limit

Parameter estimate

Note: Each figure illustrate the impact of a disaster measure on per capita income over a 5 year time period, following a disaster in period 0 . With point estimates and $95 \%$ confidence intervals. Estimates as of Table B-X in the Web Appendix.

fects is about 5 times stronger than the contemporaneous one (see Table 6). Similar findings obtain for the other disaster types except storms (for which the negative impact effect is attenuated over time.) Summarizing, there is no evidence against the simple neoclassical interpretation that natural disasters have negative growth effects on impact, with GDP per capita converging back afterwards. Hence, disasters lower the present value of per capita income.

Alternative Estimation Techniques. In our baseline estimations, we rely on the relatively long time dimension of our sample to minimize the Nickell bias. However, we have also run regressions that explicitly deal with the issue. We estimate equation 2 by applying alternative estimators such as the Anderson-Hsiao Anderson and Hsiao (1982) 
estimator, the two-step feasible GMM (IV GMM) estimator, differenced GMM (Arellano and Bond, 1991), or system GMM (Arellano and Bover, 1995; Blundell and Bond, 1998). These methods rely on using lags as instruments for endogenous variables. ${ }^{43}$

Across all methods, we find that natural disasters negatively affect income per capita. Results fully confirm our previous findings, in particular when using the aggregate disaster indices (simple and weighted). Point estimates of the disaster effect vary, but remain quantitatively similar to the baseline results. Table B-VII in the Web Appendix reports details of the results. Turning to specific disaster types, we confirm that earthquakes, storms, and temperature extremes decrease per capita income. In addition, using two-step feasible GMM in columns (2), we find also an adverse effect of droughts on income. In contrast, using systems GMM in Panel C column (4), we find only storms to have a negative impact on per capita GDP, all else insignificant.

\section{Mediating Factors}

This section explores the importance of institutional quality, and measures of openness in determining a country's ability to mitigate the consequences of natural disasters on per capita income. Besides our two aggregate disaster indexes, we use earthquakes and storms as examples of geophysical and meteorological natural disasters. ${ }^{44}$ Specifically, we estimate

$$
\Delta \ln y_{i, t}=(\rho-1) \ln y_{i, t-1}+\alpha D_{i, t}+\boldsymbol{\beta} \boldsymbol{X}_{\boldsymbol{i}, \boldsymbol{t}-\mathbf{1}}+\gamma D_{i, t} \times Z_{i, t-1}+\nu_{i}+\nu_{t}+\varepsilon_{i, t}
$$

where all variables are as above and $D_{i, t} \times Z_{i, t-1}$ captures an interaction term between the disaster variable and economic factors (degree of democratization, Sachs-Warner trade policy openness, and Chinn-Ito financial openness). The full set of country and time fixed effects and controls (including the direct effects of mediating factors) is included but not reported to conserve space. When we explore the effect of interac-

\footnotetext{
${ }^{43}$ As $\mathrm{T}$ gets large, computational requirements increase substantially. For this reason, we reduce the number of lagged values used as instruments for the two-step feasible GMM and Anderson-Hsiao to a subset of available lagged values (see also Judson and Owen, 1999). This increases the computational efficiency without significantly detracting from effectiveness. For differenced and systems GMM, we collapse available instruments to limit instrument proliferation and use the Windmeijer finite sample correction (Roodman, 2009).

${ }^{44}$ We choose the examples of earthquakes and storms due to high data quality and because previous results were the most conclusive.
} 
tions, we are aware that variables capturing disaster events are exogenous by construction, while some economic factors are potentially jointly determined with income per capita. As instruments are not readily available for most variables in the panel framework, we use the lagged value of economic variables, respectively, to attenuate the problem. We expect that higher openness makes it easier for countries to absorb the shock of a disaster because replenishing of the capital stock is sped up by the availability of foreign funds and investment goods. Also, we posit that higher values of the polity index (more democratic participation) accelerate the reconstruction effort, thereby making the effect of the disaster in its year of occurrence less dramatic.

TABLE 8

Mediating Factors (1979-2010)

Dependent Variable: $\quad \Delta \ln$ GDP per capita

\begin{tabular}{|c|c|c|c|c|}
\hline & (1) & (2) & (3) & (4) \\
\hline & \multicolumn{2}{|c|}{ Disaster indices } & \multicolumn{2}{|c|}{ Specific disasters } \\
\hline & Simple & Weighted & Earthquakes & Storms \\
\hline$D_{i, t}$ & $\begin{array}{c}-2.196^{* *} \\
(0.96)\end{array}$ & $\begin{array}{c}-2.369^{* * *} \\
(0.82)\end{array}$ & $\begin{array}{c}-35.966^{* * *} \\
(10.39)\end{array}$ & $\begin{array}{c}-9.134^{* *} \\
(4.12)\end{array}$ \\
\hline$D_{i, t} \times$ Polity $_{i, t-1}$ & $\begin{array}{c}1.817^{* *} \\
(0.87)\end{array}$ & $\begin{array}{c}1.999^{* *} \\
(0.79)\end{array}$ & $\begin{array}{c}36.903^{* * *} \\
(11.59)\end{array}$ & $\begin{array}{c}7.625^{* *} \\
(3.76)\end{array}$ \\
\hline$D_{i, t} \times$ Trade $_{i, t-1}$ & $\begin{array}{l}1.165^{*} \\
(0.61)\end{array}$ & $\begin{array}{c}1.279 * * \\
(0.51)\end{array}$ & $\begin{array}{c}14.803^{* *} \\
(6.03)\end{array}$ & $\begin{array}{l}4.613^{*} \\
(2.60)\end{array}$ \\
\hline$D_{i, t} \times$ Finance $_{i, t-1}$ & $\begin{array}{c}0.300^{* * *} \\
(0.08)\end{array}$ & $\begin{array}{c}0.273^{* * *} \\
(0.07)\end{array}$ & $\begin{array}{c}7.377^{* * *} \\
(2.14)\end{array}$ & $\begin{array}{c}1.444^{* * *} \\
(0.34)\end{array}$ \\
\hline Polity index $x_{i, t-1}$ & $\begin{array}{l}0.008 \\
(0.02)\end{array}$ & $\begin{array}{l}0.006 \\
(0.02)\end{array}$ & $\begin{array}{l}0.017 \\
(0.02)\end{array}$ & $\begin{array}{l}0.009 \\
(0.02)\end{array}$ \\
\hline Trade openness $_{i, t-1}$ & $\begin{array}{c}0.038^{* * *} \\
(0.01)\end{array}$ & $\begin{array}{c}0.039^{* * *} \\
(0.01)\end{array}$ & $\begin{array}{c}0.038^{* * *} \\
(0.01)\end{array}$ & $\begin{array}{c}0.038^{* * *} \\
(0.01)\end{array}$ \\
\hline Financial openness $s_{i, t-1}$ & $\begin{array}{l}0.007 \\
(0.01)\end{array}$ & $\begin{array}{l}0.007 \\
(0.01)\end{array}$ & $\begin{array}{l}0.008 \\
(0.01)\end{array}$ & $\begin{array}{l}0.007 \\
(0.01)\end{array}$ \\
\hline Observations & 1,719 & 1,719 & 1,719 & 1,719 \\
\hline Adjusted R2 & 0.260 & 0.258 & 0.256 & 0.259 \\
\hline
\end{tabular}

Note: ${ }^{* * *},{ }^{* *},{ }^{*}$ denote significance at the $1 \%, 5 \%$, and $10 \%$ level, respectively. Robust standard errors reported in parentheses. Controls, country and time fixed effects included but not reported. Controls are included as of Table 5 column (1). $D_{i, t}$ is the disaster measure indicated in the column headings.

Table 8 reports the results. Columns (1) and (2) report results of the aggregate in- 
dices. Both, for the unweighted and the weighted index, the direct effects of disasters on real GDP per capita are negative. The direct effect of the polity index and the ChinnIto index of financial openness are positive (indicating that more democratic institutions and higher financial openness spur growth), but statistically insignificant. ${ }^{45}$ The Sachs-Warner index of trade openness, in contrast, is positive and statistically significant. Countries in autarky (index of 0 ) forego a positive growth effect reaching up to $3.8 \%$ in the case of complete openness. This sign and significance pattern is repeated in column (2). It also holds when looking at specific types of natural disasters only, see columns (3) and (4).

Because the mediating factors exhibit strong pairwise correlation, which impairs the exact attribution of quantitative effects, for illustration, we use a regression design that includes only one interaction term at the time; see Table in the Web Appendix. ${ }^{46}$ We evaluate the estimates at different percentiles of the disaster intensity distribution and at high, medium, and low values of the mediating factors. Starting with the democratic orientation of countries, we find that a (weighted) disaster index belonging to the $95 \%$ worst realizations, lowers GDP per capita by at least $2.26 \%$ in autocratic countries (rescaled polity IV index of 0.05 ), but only by $0.29 \%$ in countries half way to democratic institutions (polity IV index of 0.45). A disaster year at the $75 \%$ percentile lowers GDP by at least $0.50 \%$ for autocratic countries, and by at least $0.06 \%$ for mixed regimes. A similar picture emerges for the unweighted disaster index and for earthquakes or storms. So, democratic countries suffer dramatically lower GDP losses from disasters of given physical strength.

Similarly, the openness measures also help mitigating the negative impact effects of disasters on GDP per capita. Focusing on the robustly significant financial openness indicator, we find that a disaster year belonging to the $95 \%$ percentile of the weighted disaster index, produces a GDP per capita loss of $2.12 \%$ if the country is financially very closed (Chinn-Ito index of 0.1 ). If the country has intermediate openness of 0.4 , the damage of the same disaster intensity is $1.43 \%$ of GDP per capita, while it is 0.50 for financially open countries (Chinn-Ito index of 0.8 ). A disaster year at the 75th per-

\footnotetext{
${ }^{45}$ This is most likely due to the fact that identification of the effects of these slow-moving variables is hard in the presence of country fixed effects.

${ }^{46}$ While this setup reproduces the sign pattern obtained in Table 8 qualitatively, the trade openness indicator does not turn out statistically significant. Results on financial openness and democratic orientation hold up.
} 
centile reduces GDP per capita by $0.47 \%, 0.32 \%$ and $0.11 \%$ for countries with low $(0.1)$, intermediate (0.4), and high (0.8) levels of financial openness, respectively.

Hence, financial openness helps deal with natural catastrophes, but the mitigating power of inclusive democratic institutions seems to be quantitatively more important. The empirical evidence for trade openness as a mediating factor is, however, weaker.

\section{Concluding Remarks}

In the present paper, we present a new database on natural disasters which is based on primary geophysical and meteorlogical sources, and covers more than hundred countries over the years 1979 to 2010. Our data is suitable for a causal analysis of the impact of natural disasters on GDP per capita, as it builds on physical measures of disaster intensity, such as Richter scale, VEI, wind speed, precipitation, and temperature.

We show that disaster information obtained from insurance data or news (e.g., the so called EM-DAT data set) are not well suited for causal analysis. First, those data suffer from a selection issue as the probability of a disaster with given physical magnitude to be included depends on the affected country's GDP per capita. Second, monetary disaster intensity measures correlate with GDP per capita of the affected country. These features make it likely that regressing natural disasters on GDP per capita leads to upwards-biased estimates.

In a next step, we examine the impact of natural disasters on per capita GDP. Our findings provide very pervasive evidence that natural disasters do indeed lower GDP per capita temporarily. Our key findings are: A disaster in the top 1-percentile of the disaster index distribution reduces GDP per capita by at least $6.83 \%$, while the top 5percentile disasters cause per capita income to drop at least by $0.33 \%$, and the smallest 25 -percentile disasters cut GDP per capita by at most $0.01 \%$. Results vary across country samples, with low and middle income countries experiencing the highest losses, and across disaster types. These findings are well in line with a very simple neoclassical growth model, in which disasters destroy part of the capital stock and where growth in later periods is temporarily higher because of convergence to steady state. We do not find, that growth in later periods is higher due to the disaster itself.

Moreover, we show that better institutional quality, higher openness to trade, and 
higher financial openness help spur the economic reconstruction process so that the adverse effect of a natural disaster on per capita income is reduced.

We believe that our comprehensive GeoMet data on pure physical disaster intensity measures can be fruitfully applied to many other questions, including the relation between disasters and trade patterns, migration patterns, poverty, inequality, consumption, and investment decisions, and many more. 


\section{References}

Albala-Bertrand, J., 1993. Natural Disaster Situations and Growth: A Macroeconomic Model for Sudden Disaster Impacts. World Development 21 (9), 1417-1434.

Anderson, T., Hsiao, C., 1982. Formulation and Estimation of Dynamic Models using Panel Data. Journal of Econometrics 18 (1), 47-82.

Arellano, M., Bond, S., 1991. Some Tests of Specification for Panel Data: Monte Carlo Evidence and an Application to Employment Equations. Review of Economic Studies 58 (2), 277-297.

Arellano, M., Bover, O., 1995. Another Look at the Instrumental Variable Estimation of Error-Components Models. Journal of Econometrics 68 (1), 29-51.

Blundell, R., Bond, S., 1998. Initial Conditions and Moment Restrictions in Dynamic Panel Data Models. Journal of Econometrics 87 (1), 115-143.

Brückner, M., Ciccone, A., 2011. Rain and the Democratic Window of Opportunity. Econometrica 79 (3), 923-947.

Caballero, R., Hammour, M., 1994. The Cleansing Effect of Recessions. American Economic Review 84 (5), 1350-68.

Caselli, F., Esquivel, G., Lefort, F., 1996. Reopening the Convergence Debate: A New Look at Cross-Country Growth Empirics. Journal of Economic Growth 1 (3), 363-389.

Cavallo, E., Galiani, S., Noy, I., Pantano, J., forthcoming. Catastrophic Natural Disasters and Economic Growth. Review of Economics and Statistics.

Chu, D., Kaufman, Y., Ichoku, C., Remer, L., Tanré, D., Holben, B., 2002. Validation of MODIS Aerosol Optical Depth Retrieval over Land. Geophysical Research Letters 29 (12), 8007.

Eichengreen, B., Rose, A., Wyplosz, C., Dumas, B., Weber, A., 1995. Exchange Market Mayhem: The Antecedents and Aftermath of Speculative Attacks. Economic Policy 10, 249-312.

Felbermayr, G., Gröschl, J., 2013. Natural Disasters and the Effect of Trade on Income: A New Panel IV Approach. European Economic Review 58 (C), 18-30.

Fomby, T., Ikeda, Y., Loayza, N., 2013. The Growth Aftermath of Natural Disasters. Journal of Applied Econometrics 28 (3), 412-434.

GDV-Gesamtverband der Deuschen Versicherungswirtschaft, 2012. Statistisches Taschenbuch der Versicherungswirtschaft. GDV, Berlin.

Hallegatte, S., Dumas, P., 2009. Can Natural Disasters Have Positive Consequences? Investigating the Role of Embodied Technical Change. Ecological Economics 68 (3), 777-786. 
Hallegatte, S., Przyluski, V., 2010. The Economics of Natural Disasters. CESifo Forum (2), $14-24$.

Hochrainer, S., 2009. Assessing the Macroeconomic Impacts of Natural Disasters: Are There Any? World Bank Policy Research Working Paper 4968.

Ikefuji, M., Horii, R., 2012. Natural Disasters in a Two-Sector Model of Endogenous Growth. Journal of Public Economics 96, 784-796.

Islam, N., 1995. Growth Empirics: A Panel Data Approach. Quarterly Journal of Economics 110 (4), 1127-1170.

Judson, R., Owen, A., 1999. Estimating Dynamic Panel Data Models: A Guide for Macroeconomists. Economics Letters 65 (1), 9-15.

Kahn, M., 2005. The Death Toll from Natural Disasters: The Role of Income, Geography, and Institutions. Review of Economics and Statistics 87 (2), 271-284.

Klenow, P., Rodriguez-Clare, A., 1997. Economic Growth: A Review Essay. Journal of Monetary Economics 40 (3), 597-617.

Leiter, A., Oberhofer, H., Raschky, P., 2009. Creative Disasters? Flooding Effects on Capital, Labour and Productivity Within European Firms. Environmental and Resource Economics 43 (3), 333-350.

Levin, A., Lin, C.-F., James Chu, C.-S., 2002. Unit Root Tests in Panel Data: Asymptotic and Finite-Sample Properties. Journal of Econometrics 108 (1), 1-24.

Loayza, N., Eduardo, O., Rigolini, J., Christiaensen, L., 2012. Natural Disasters and Growth: Going Beyond the Averages. World Development 40 (7), 1317-1336.

Mankiw, N., Romer, D., Weil, D., 1992. A Contribution to the Empirics of Economic Growth. Quarterly Journal of Economics 107 (2), 407-437.

Miguel, E., Satyanath, S., Sergenti, E., 2004. Economic Shocks and Civil Conflict: An Instrumental Variables Approach. Journal of Political Economy 112 (4), 725-753.

Munich Re, 2006. Topics Geo Annual Review: Natural Catastrophes 2005. Münchener Rückversicherungs-Gesellschaft.

Narita, D., Tol, R., Anthoff, D., 2010. Economic Costs of Extratropical Storms Under Climate Change: An Application of FUND. Journal of Environmental Planning and Management 53 (3), 371-384.

National Hurricane Center, 1999. Hurricane Basics. National Oceanic and Atmospheric Administration (NOAA).

Nickell, S., 1981. Biases in Dynamic Models with Fixed Effects. Econometrica, 14171426. 
Noy, I., 2009. The Macroeconomic Consequences of Disasters. Journal of Development Economics 88 (2), 221-231.

Raddatz, C., 2007. Are External Shocks Responsible for the Instability of Output in LowIncome Countries? Journal of Development Economics 84 (1), 155-187.

Raddatz, C. E., 2009. The Wrath of God: Macroeconomic Costs of Natural Disasters. World Bank Policy Research Working Paper 5039.

Roodman, D., 2009. xtabond2: Stata Module to Extend xtabond Dynamic Panel Data Estimator. Stata Journal 9, 86-136.

Sachs, J., Warner, A., 1995. Economic Reform and the Process of Global Integration. Brookings Papers on Economic Activity 1995 (1), 1-118.

Skidmore, M., Toya, H., 2002. Do Natural Disasters Promote Long-Run Growth? Economic Inquiry 40 (4), 664-687.

Soretz, S., 2007. Efficient Dynamic Pollution Taxation in an Uncertain Environment. Environmental and Resource Economics 36 (1), 57-84.

Strobl, E., 2011. The Economic Growth Impact of Hurricanes: Evidence from US Coastal Counties. Review of Economics and Statistics 93 (2), 575-589.

Toya, H., Skidmore, M., 2007. Economic Development and the Impacts of Natural Disasters. Economics Letters 94 (1), 20-25.

Wacziarg, R., Welch, K., 2008. Trade Liberalization and Growth: New Evidence. World Bank Economic Review 22 (2), 187-231.

Yang, D., 2008. Coping with disaster: The Impact of Hurricanes on International Financial Flows, 1970-2002. BE Journal of Economic Analysis \& Policy 8 (1), Article 13. 


\section{A Appendix}

TABLE A-I

Summary Table, Full Sample $(N=1,787)$

\begin{tabular}{|c|c|c|c|c|}
\hline Variable & Mean & Std. Dev. & Source & Description \\
\hline$\Delta \ln$ GDP per capita ${ }_{i, t}$ & 0.049 & 0.057 & PWT (7.0) & Per capita GDP PPP growth. \\
\hline $\ln$ GDP per capita ${ }_{i, t-1}$ & 8.528 & 1.215 & PWT (7.0) & GDP per capita. \\
\hline $\ln$ population $_{i, t-1}$ & 9.666 & 1.441 & PWT (7.0) & Total population in thousands. \\
\hline Polity index int-1 $_{i, t}$ & 0.733 & 0.313 & Polity IV (2010) & Polity index, normalized between 0 and 1. \\
\hline Trade openness $_{i, t-1}$ & 0.744 & 0.497 & $\operatorname{PWT}(7.0)$ & Imports plus exports over GDP. \\
\hline Interest rate r $_{i, t-1}$ & 0.007 & 0.012 & WDI (2012) & Real interest rate. \\
\hline Domestic credit $_{i, t-1}$ & 0.635 & 0.496 & WDI (2012) & $\begin{array}{l}\text { Domestic credit in banking sector (share of } \\
\text { GDP). }\end{array}$ \\
\hline Gross capital formation $_{i, t-1}$ & 0.053 & 0.169 & WDI (2012) & Gross capital formation (share of growth). \\
\hline Foreign direct investment $t_{i, t-1}$ & 0.028 & 0.043 & WDI (2012) & $\begin{array}{l}\text { Foreign direct investment, net inflows (share } \\
\text { of GDP). }\end{array}$ \\
\hline ln Inflation Int-1 $_{i}$ & -5.148 & 1.212 & WDI (2012) & Inflation, consumer prices. \\
\hline Current account balance $_{i, t-1}$ & -0.018 & 0.070 & WDI (2012) & Current account balance (share of GDP) \\
\hline Trade policy openness $s_{i}$ & 0.593 & 0.491 & $\begin{array}{l}\text { Sachs \& Warner (1995), } \\
\text { Wacziarg \& Welch (2008) }\end{array}$ & $\begin{array}{l}\text { Index of trade policy openness constructed } \\
\text { by Sachs and Warner (1995), extended by } \\
\text { Wacziarg and Welch (2008). }\end{array}$ \\
\hline Financial openness $_{i, t-1}$ & 1,757 & 0.457 & 0.306 & Chinn \& Ito (2010) \\
\hline \multicolumn{5}{|l|}{$\begin{array}{l}\text { Financial (capital account) open- } \\
\text { ness. }\end{array}$} \\
\hline Richter scale $_{i, t}$ & 0.009 & 0.061 & GeoMet-Data & Max. Richter scale by land area. \\
\hline $\mathrm{VEI}_{i, t}$ & 0.009 & 0.044 & GeoMet-Data & Max. Volcanic Eruption Index by land area. \\
\hline Wind speed $_{i, t}$ & 0.009 & 0.045 & GeoMet-Data & Max. wind speed in knots by land area. \\
\hline Positive $\Delta \operatorname{rain}_{i, t}$ & 0.053 & 0.013 & GeoMet-Data & $\begin{array}{l}\text { Max. positive difference in monthly rainfall } \\
\text { from long run monthly mean by land area. }\end{array}$ \\
\hline Drought $_{i, t}$ & 0.009 & 0.127 & GeoMet-Data & $\begin{array}{l}\text { One if precipitation in three months in a row, } \\
\text { or at least in } 5 \text { months a year } 50 \% \text { below long } \\
\text { run monthly precipitation mean, zero other- } \\
\text { wise, by land area. }\end{array}$ \\
\hline Absolute $\Delta$ temperature $_{i, t}$ & 0.009 & 0.004 & GeoMet-Data & $\begin{array}{l}\text { Max. absolute difference in monthly tempera- } \\
\text { ture from long run monthly mean by land area. }\end{array}$ \\
\hline Disaster Index $_{i, t}$ & 0.041 & 0.199 & GeoMet-Data & Sum of disaster types by land area. \\
\hline Disaster Index, weighted ${ }_{i, t}$ & 0.041 & 0.209 & GeoMet-Data & $\begin{array}{l}\text { Sum of disaster types weighted by country } \\
\text { specific inverse of standard deviations by land } \\
\text { area. }\end{array}$ \\
\hline EMDAT All Disaster $_{i, t}$ & 0.001 & 0.003 & EM-DAT (2012) & All disasters by land area. \\
\hline EMDAT Large Disaster $_{i, t}$ & 0.0002 & 0.001 & EM-DAT (2012) & $\begin{array}{l}\text { Large-scale disasters by land area, as defined } \\
\text { by decision rule. }\end{array}$ \\
\hline NatCatSERVICE All Disaster $_{i, t}$ & 0.004 & 0.021 & Munich Re (2012) & All disasters by land area. \\
\hline NatCatSERVICE Large Disaster $_{i, t}$ & 0.00004 & 0.0003 & Munich Re (2012) & $\begin{array}{l}\text { Large-scale disasters by land area, as defined } \\
\text { by decision rule. }\end{array}$ \\
\hline
\end{tabular}




\section{B Web Appendix (not for publication)}

This is the Web Appendix to Felbermayr, Gabriel and Jasmin Gröschl (2013), Naturally Negative: The Growth Effects of Natural Disasters, CESifo Working Paper. The full paper can be requested at felbermayr@ifo.de.

FIGURE B-I

Intensity distributions of disasters in EM-DAT versus GeoMet
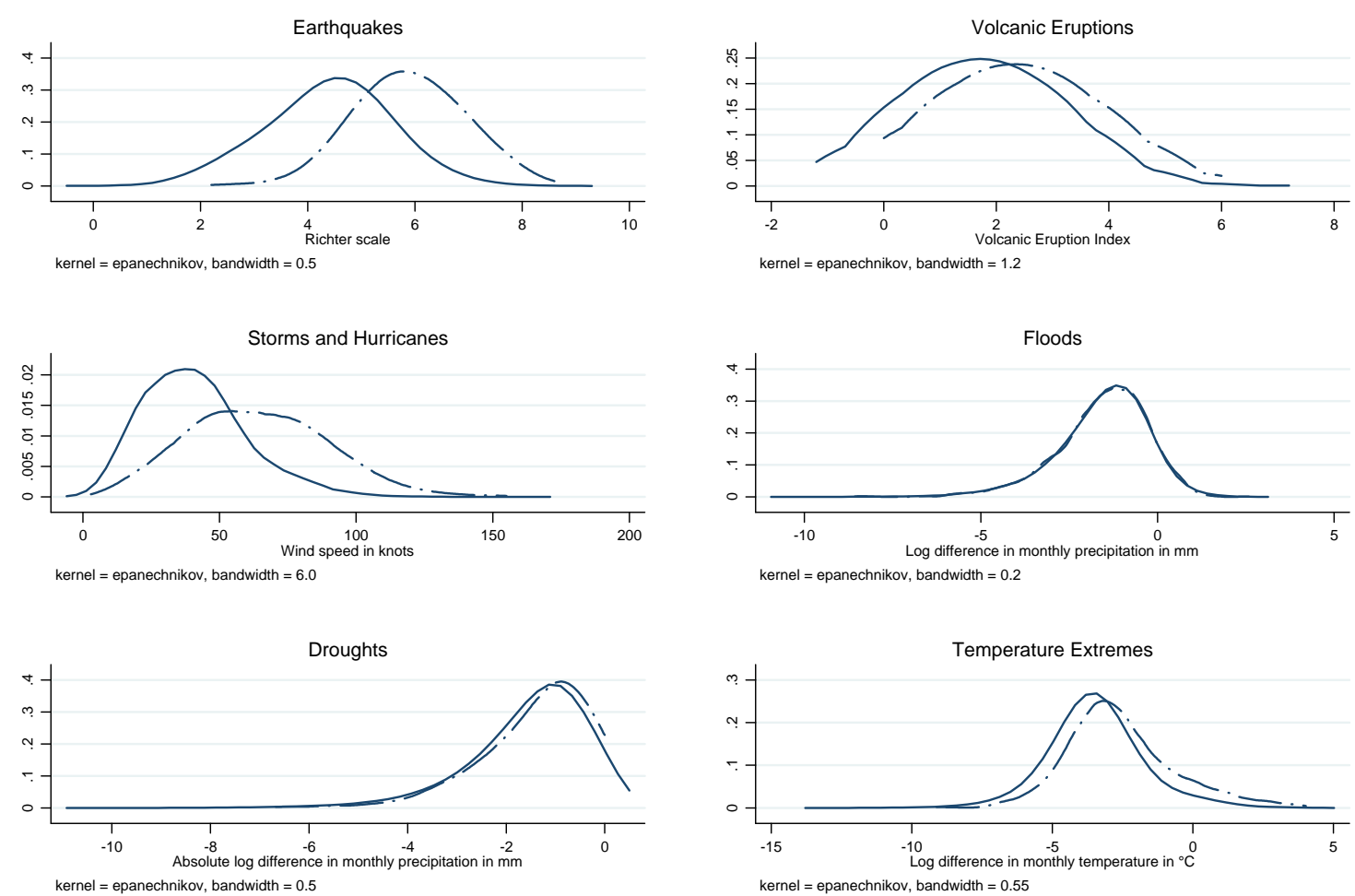
kernel $=$ epanechnikov, bandwidth $=0.5$

GeoMet-Data

EM-DAT

Note: Kernel densities by disaster type. Intensity measures by reports using the matched event-based database (EM-DAT and GeoMet). 
FIGURE B-II

Kernel densities of earthquake intensities 1990-2000 and 2000-2010, GeoMet data

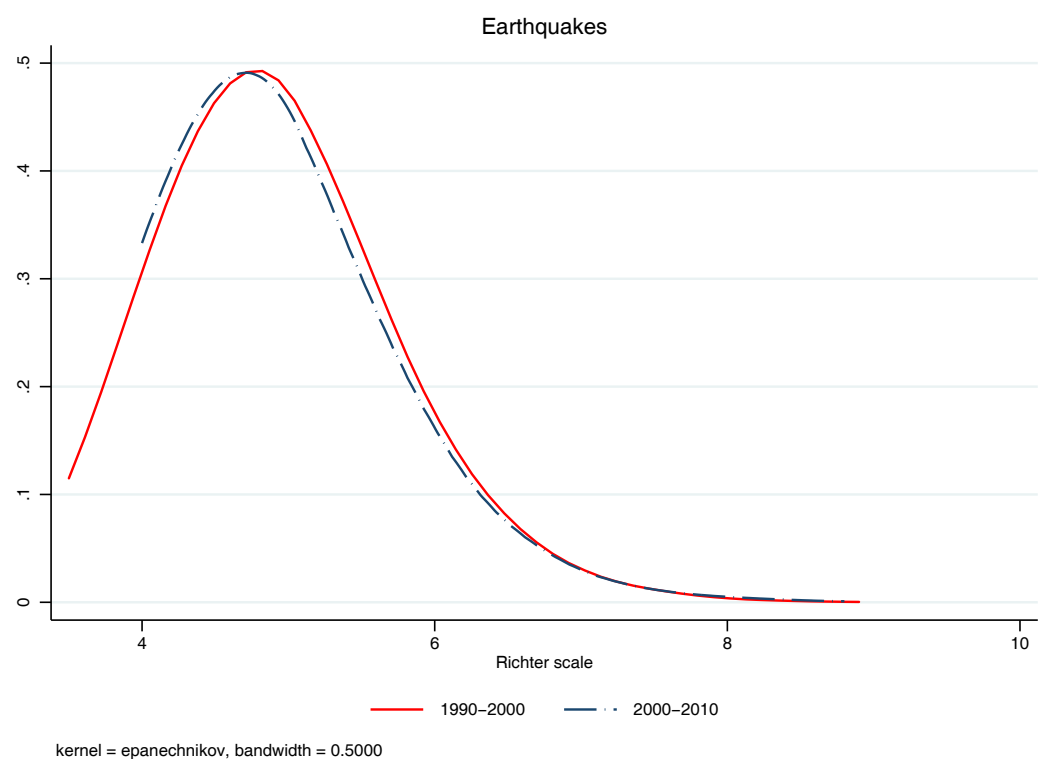

FIGURE B-III

Kernel densities of storms and hurricanes 1990-2000 and 2000-2010, GeoMet data

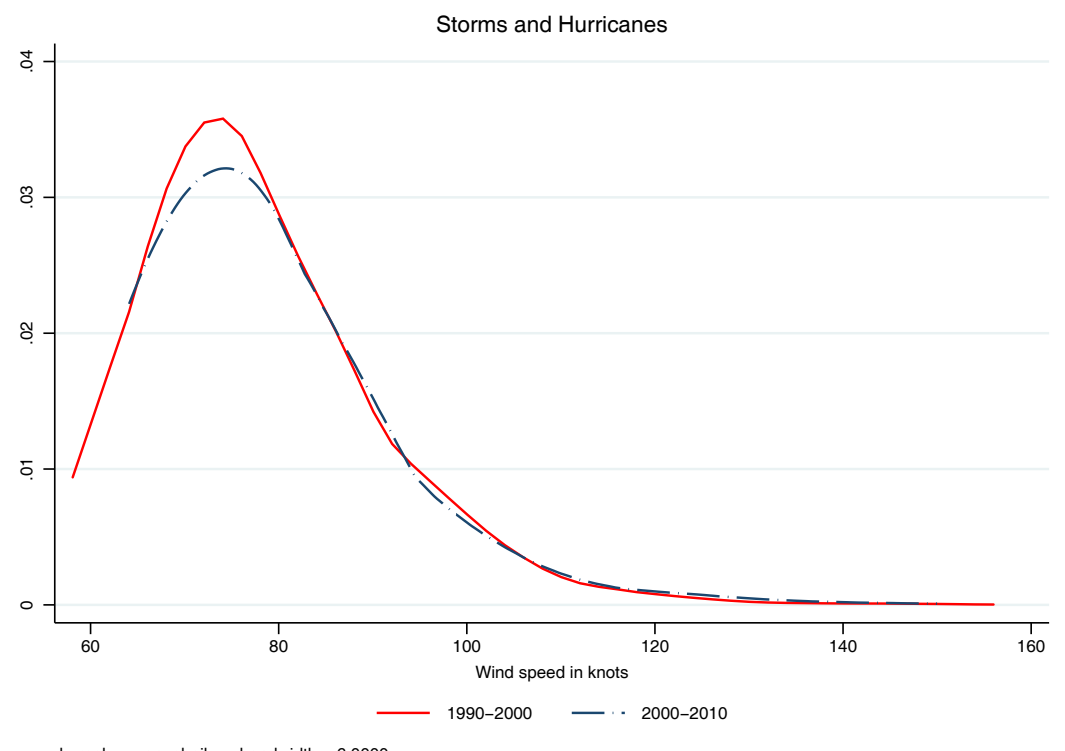

kernel $=$ epanechnikov, bandwidth $=6.0000$ 


\section{FIGURE B-IV}

Distribution of disasters over GDP per capita levels in EM-DAT versus GeoMet
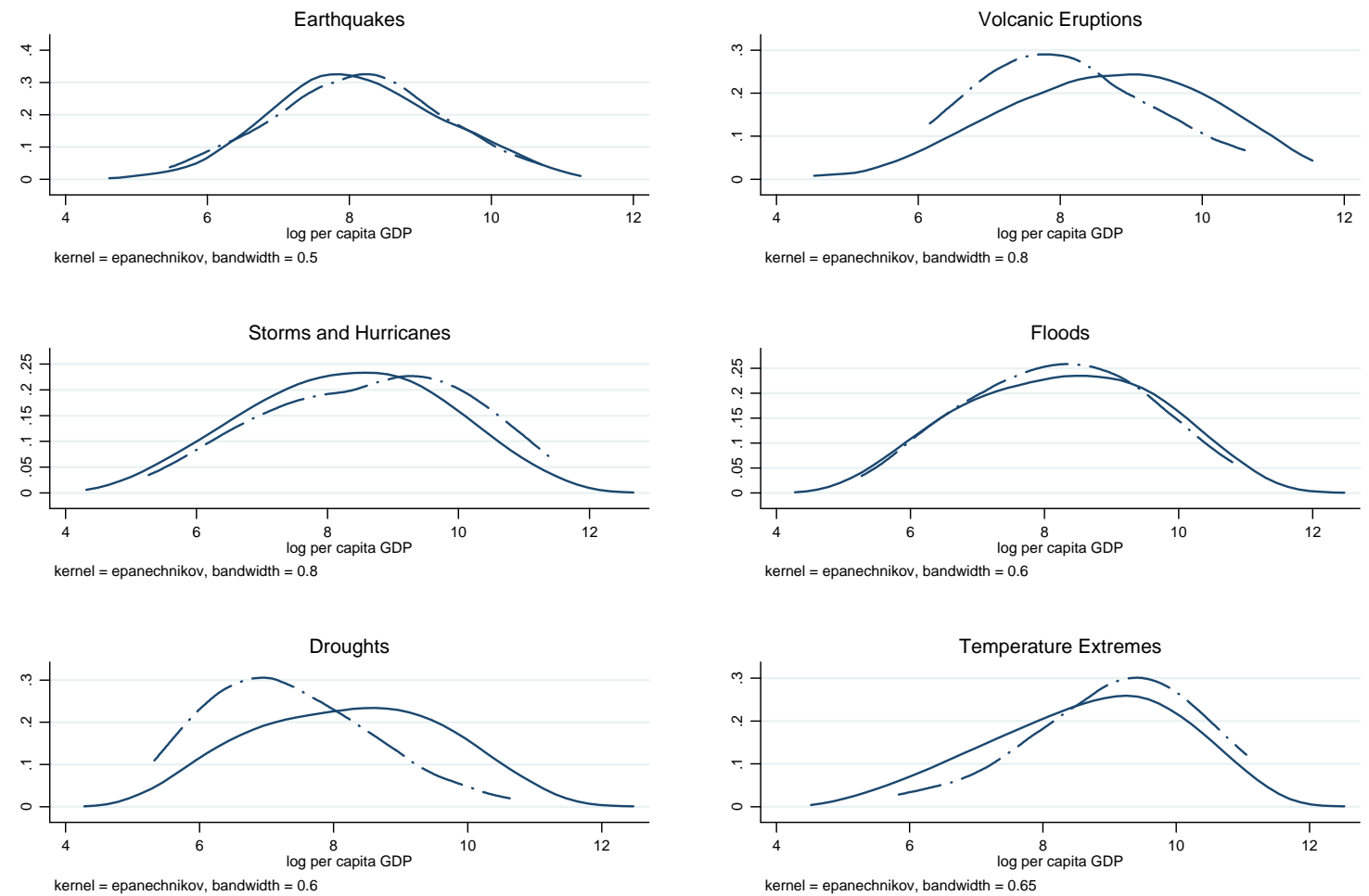

GeoMet-Data

EM-DAT

Note: Kernel densities by disaster type. Log GDP per capita distribution by disaster reported using the matched event-based database (EM-DAT and GeoMet data). 
TABLE B-I

EM-DAT costs by physical magnitude, matched event-based data (1979-2010)

\begin{tabular}{|c|c|c|c|c|}
\hline \multicolumn{5}{|c|}{ Physical Magnitude Scale } \\
\hline \multicolumn{5}{|c|}{ PANEL A: EARTHQUAKES } \\
\hline Richter scale & $5-6$ & $6-7$ & $7-8$ & $>=8$ \\
\hline Total observations & 8,065 & 2,058 & 303 & 22 \\
\hline thereof reported in EM-DAT & 281 & 252 & 110 & 9 \\
\hline Killed over pop (\%) & 0.001 & 0.001 & 0.028 & 0.011 \\
\hline Affected over pop (\%) & 0.271 & 0.281 & 0.730 & 1.074 \\
\hline Damage over GDP (\%) & 0.402 & 0.375 & 1.499 & 1.841 \\
\hline \multicolumn{5}{|c|}{ PANEL B: VOLCANO ERUPTIONS } \\
\hline Volcanic Explosivity & $2-3$ & $3-4$ & $4-5$ & $>=5$ \\
\hline Total observations & 370 & 147 & 22 & 4 \\
\hline thereof reported in EM-DAT & 35 & 32 & 10 & 3 \\
\hline Killed over pop (\%) & 0.00003 & 0.008 & 0.0001 & 0.001 \\
\hline Affected over pop (\%) & 0.094 & 0.958 & 0.577 & 0.698 \\
\hline Damage over GDP (\%) & 0.003 & 0.282 & 0.444 & 0.082 \\
\hline \multicolumn{5}{|c|}{ PANEL C: STORMS } \\
\hline Storm Category & Tropical & Scale 1 & Scale 2 & $>=$ Scale 3 \\
\hline Wind Speed in knots & $33-63$ & $64-82$ & $83-95$ & $>=96$ \\
\hline Total observations & 38,798 & 5,890 & 1,232 & 600 \\
\hline thereof reported in EM-DAT & 856 & 556 & 247 & 230 \\
\hline Killed over pop (\%) & 0.0004 & 0.0002 & 0.0002 & 0.003 \\
\hline Affected over pop (\%) & 1.021 & 0.680 & 2.266 & 4.188 \\
\hline Damage over GDP (\%) & 11.261 & 0.413 & 0.604 & 1.678 \\
\hline \multicolumn{5}{|c|}{ PANEL D: FLOODS } \\
\hline Positive $\Delta$ Precipitation & {$[0.387,0.782]$} & {$[0.783,1.17]$} & {$[1.18,1.953]$} & $>=1.954$ \\
\hline Total observations & 7,206 & 2,449 & 1,406 & 709 \\
\hline thereof reported in EM-DAT & 448 & 150 & 96 & 34 \\
\hline Killed over pop (\%) & 0.0002 & 0.0003 & 0.001 & 0.003 \\
\hline Affected over pop (\%) & 0.837 & 1.096 & 0.992 & 4.546 \\
\hline Damage over GDP (\%) & 0.181 & 0.547 & 0.409 & 0.578 \\
\hline \multicolumn{5}{|c|}{ PANEL E: DROUGHTS } \\
\hline Negative $\Delta$ Precipitation & {$[-0.362,-0.150]$} & {$[-0.626,-0.363]$} & {$[-0.890,-0.627]$} & $<=-0.890$ \\
\hline Total observations & 13,722 & 10,723 & 5,008 & 1,004 \\
\hline thereof reported in EM-DAT & 140 & 126 & 77 & 26 \\
\hline Killed over pop (\%) & 0.088 & 0.088 & 0.098 & 0.670 \\
\hline Affected over pop (\%) & 12.252 & 18.559 & 24.110 & 18.895 \\
\hline Damage over GDP (\%) & 0.287 & 0.436 & 0.806 & 0.029 \\
\hline \multicolumn{5}{|c|}{ PANEL F: EXTREME TEMPERATURE } \\
\hline Absolute $\Delta$ Temperature & {$[0.011,0.025]$} & {$[0.026,0.050]$} & {$[0.051,0.100]$} & $>=0.101$ \\
\hline Total observations & 14,421 & 12,489 & 9,640 & 12,917 \\
\hline thereof reported in EM-DAT & 246 & 57 & 64 & 120 \\
\hline Killed over pop (\%) & 0.0003 & 0.0002 & 0.004 & 0.001 \\
\hline Affected over pop (\%) & 0.347 & 0.062 & 0.744 & 1.651 \\
\hline Damage over GDP (\%) & 0.030 & 0.067 & 0.121 & 0.491 \\
\hline
\end{tabular}

Note: Event-based dataset (GeoMet). The decision rule on large disasters in EM-DAT builds on the convention of Munich Re (2006). Large-scale disasters are defined as events that (i) caused 1,000 or more injured or dead; (ii) affected 100,000 or more persons; or (iii) caused a monetary damage of 1 billion or more US dollars. 
TABLE B-II

Controls: EM-DAT Probability of Disaster Reporting, Matched Event-Based, Fixed-Effects (1979-2010)

\begin{tabular}{|c|c|c|c|c|c|c|}
\hline \multirow[t]{3}{*}{ Dependent Variable: } & \multicolumn{6}{|c|}{ Variable equals one if disaster is reported in EM-DAT } \\
\hline & Earthquakes & & & & Droughts & Extreme \\
\hline & (1) & (2) & (3) & (4) & (5) & (6) \\
\hline Richter scale & $\begin{array}{c}0.060^{* * *} \\
(0.00)\end{array}$ & & & & & \\
\hline Volcanic Explosivity Index & & $\begin{array}{c}0.110^{* * *} \\
(0.02)\end{array}$ & & & & \\
\hline Wind speed & & & $\begin{array}{c}0.002^{* * *} \\
(0.00)\end{array}$ & & & \\
\hline$\Delta$ precipitation & & & & $\begin{array}{c}0.037^{* * *} \\
(0.00)\end{array}$ & $\begin{array}{l}0.002 \\
(0.00)\end{array}$ & \\
\hline$\Delta$ temperature & & & & & & $\begin{array}{c}0.001^{* *} \\
(0.00)\end{array}$ \\
\hline ln GDP per capita & $\begin{array}{c}0.019^{* *} \\
(0.01)\end{array}$ & $\begin{array}{l}-0.102 \\
(0.07)\end{array}$ & $\begin{array}{r}-0.007 \\
(0.01)\end{array}$ & $\begin{array}{l}0.002 \\
(0.01)\end{array}$ & $\begin{array}{l}-0.003 \\
(0.00)\end{array}$ & $\begin{array}{c}-0.002 \\
(0.00)\end{array}$ \\
\hline ln population & $\begin{array}{l}-0.006 \\
(0.01)\end{array}$ & $\begin{array}{l}0.047 \\
(0.17)\end{array}$ & $\begin{array}{c}-0.028^{* * *} \\
(0.01)\end{array}$ & $\begin{array}{c}0.045^{* * *} \\
(0.01)\end{array}$ & $\begin{array}{l}0.005 \\
(0.01)\end{array}$ & $\begin{array}{c}-0.032^{* * *} \\
(0.01)\end{array}$ \\
\hline Polity index & $\begin{array}{c}0.016^{*} \\
(0.01)\end{array}$ & $\begin{array}{l}0.015 \\
(0.08)\end{array}$ & $\begin{array}{l}0.008 \\
(0.01)\end{array}$ & $\begin{array}{c}0.017^{* *} \\
(0.01)\end{array}$ & $\begin{array}{l}0.000 \\
(0.00)\end{array}$ & $\begin{array}{l}0.002 \\
(0.00)\end{array}$ \\
\hline Financial openness & $\begin{array}{c}-0.018^{* * *} \\
(0.01)\end{array}$ & $\begin{array}{l}0.065 \\
(0.07)\end{array}$ & $\begin{array}{l}0.008 \\
(0.01)\end{array}$ & $\begin{array}{l}-0.009 \\
(0.01)\end{array}$ & $\begin{array}{l}0.001 \\
(0.00)\end{array}$ & $\begin{array}{c}-0.001 \\
(0.00)\end{array}$ \\
\hline Trade policy openness & $\begin{array}{c}0.066^{* * *} \\
(0.02)\end{array}$ & $\begin{array}{c}-1.002 \\
(0.84)\end{array}$ & $\begin{array}{c}-0.003 \\
(0.03)\end{array}$ & $\begin{array}{l}-0.097 \\
(0.07)\end{array}$ & $\begin{array}{c}-0.090^{* *} \\
(0.04)\end{array}$ & $\begin{array}{c}0.032^{* * *} \\
(0.01)\end{array}$ \\
\hline UN vote correlation & $\begin{array}{c}0.038^{* *} \\
(0.02)\end{array}$ & $\begin{array}{l}-0.136 \\
(0.20)\end{array}$ & $\begin{array}{c}-0.060^{* * *} \\
(0.02)\end{array}$ & $\begin{array}{l}-0.023 \\
(0.02)\end{array}$ & $\begin{array}{c}-0.020^{*} \\
(0.01)\end{array}$ & $\begin{array}{c}0.026^{* * *} \\
(0.01)\end{array}$ \\
\hline Observations & 22,811 & 796 & 41,867 & 44,136 & 44,136 & 41,859 \\
\hline Adjusted $R^{2}$ & 0.140 & 0.173 & 0.213 & 0.092 & 0.018 & 0.029 \\
\hline
\end{tabular}

Note: ${ }^{* * *},{ }^{* *},{ }^{*}$ denote significance at the $1 \%, 5 \%$, and $10 \%$ level, respectively. Country and time fixed effects included but not reported. All estimations use a linear probability specification. Matched event-based database (EM-DAT + GeoMet-Data). 
TABLE B-III

Controls: NatCatSERVICE Probability of Disaster Reporting, Matched Event-Based, Fixed-Effects (1979-2010)

\begin{tabular}{|c|c|c|c|c|c|c|}
\hline \multirow[t]{2}{*}{ Dependent Variable: } & \multicolumn{6}{|c|}{ Variable equals one if disaster is reported in NatCatSERVICE } \\
\hline & Earthquakes & Volcano & Storms & Floods & Droughts & $\begin{array}{c}\text { Extreme } \\
\text { Temperature }\end{array}$ \\
\hline Richter scale & $\begin{array}{c}0.106^{* * *} \\
(0.00)\end{array}$ & & & & & \\
\hline Volcanic Explosivity Index & & $\begin{array}{c}0.168^{* * *} \\
(0.02)\end{array}$ & & & & \\
\hline Wind speed & & & $\begin{array}{c}0.003^{* * *} \\
(0.00)\end{array}$ & & & \\
\hline$\Delta$ precipitation & & & & $\begin{array}{c}0.055^{* * *} \\
(0.00)\end{array}$ & $\begin{array}{c}0.003^{* * *} \\
(0.00)\end{array}$ & \\
\hline$\Delta$ temperature & & & & & & $\begin{array}{c}0.002^{* * *} \\
(0.00)\end{array}$ \\
\hline ln GDP per capita & $\begin{array}{c}0.083^{* * *} \\
(0.01)\end{array}$ & $\begin{array}{l}0.038 \\
(0.09)\end{array}$ & $\begin{array}{c}0.019^{* * *} \\
(0.01)\end{array}$ & $\begin{array}{c}0.039^{* * *} \\
(0.01)\end{array}$ & $\begin{array}{l}0.003 \\
(0.00)\end{array}$ & $\begin{array}{l}0.002 \\
(0.00)\end{array}$ \\
\hline ln population & $\begin{array}{l}0.031 \\
(0.02)\end{array}$ & $\begin{array}{l}0.183 \\
(0.23)\end{array}$ & $\begin{array}{c}-0.102^{* * *} \\
(0.02)\end{array}$ & $\begin{array}{l}0.024^{*} \\
(0.01)\end{array}$ & $\begin{array}{l}-0.003 \\
(0.01)\end{array}$ & $\begin{array}{c}-0.040^{* * *} \\
(0.01)\end{array}$ \\
\hline Polity index & $\begin{array}{l}0.011 \\
(0.01)\end{array}$ & $\begin{array}{l}-0.017 \\
(0.09)\end{array}$ & $\begin{array}{c}-0.011 \\
(0.01)\end{array}$ & $\begin{array}{c}0.017^{* *} \\
(0.01)\end{array}$ & $\begin{array}{l}-0.002 \\
(0.00)\end{array}$ & $\begin{array}{l}0.002 \\
(0.00)\end{array}$ \\
\hline Financial openness & $\begin{array}{c}-0.053^{* * *} \\
(0.01)\end{array}$ & $\begin{array}{l}0.027 \\
(0.08)\end{array}$ & $\begin{array}{c}-0.028^{* * *} \\
(0.01)\end{array}$ & $\begin{array}{c}-0.022^{* * *} \\
(0.01)\end{array}$ & $\begin{array}{c}-0.003 \\
(0.00)\end{array}$ & $\begin{array}{c}-0.002 \\
(0.00)\end{array}$ \\
\hline Trade policy openness & $\begin{array}{c}0.132^{* * *} \\
(0.03)\end{array}$ & $\begin{array}{l}-1.612 \\
(1.10)\end{array}$ & $\begin{array}{c}-0.545^{* * *} \\
(0.11)\end{array}$ & $\begin{array}{c}-0.198^{* *} \\
(0.08)\end{array}$ & $\begin{array}{c}-0.109 * * * \\
(0.03)\end{array}$ & $\begin{array}{c}-0.210^{* * *} \\
(0.04)\end{array}$ \\
\hline UN vote correlation & $\begin{array}{l}0.014 \\
(0.03)\end{array}$ & $\begin{array}{l}0.257 \\
(0.28)\end{array}$ & $\begin{array}{c}-0.043^{*} \\
(0.03)\end{array}$ & $\begin{array}{c}-0.052^{*} \\
(0.03)\end{array}$ & $\begin{array}{c}-0.011 \\
(0.01)\end{array}$ & $\begin{array}{l}-0.014 \\
(0.01)\end{array}$ \\
\hline $\begin{array}{l}\text { Observations } \\
\text { Adjusted } R^{2}\end{array}$ & $\begin{array}{c}22,817 \\
0.186\end{array}$ & $\begin{array}{c}874 \\
0.254\end{array}$ & $\begin{array}{c}41,717 \\
0.285\end{array}$ & $\begin{array}{c}44,136 \\
0.133\end{array}$ & $\begin{array}{c}44,136 \\
0.014\end{array}$ & $\begin{array}{c}41,858 \\
0.046\end{array}$ \\
\hline
\end{tabular}

Note: ${ }^{* * *},{ }^{* *},{ }^{*}$ denote significance at the $1 \%, 5 \%$, and $10 \%$ level, respectively. Country and time fixed effects included but not reported. All estimations use a linear probability specification. Matched event-based database (NatCatSERVICE + GeoMet-Data). 
TABLE B-IV

GDP per capita Growth and Natural Disasters, Parsimonious Model (fixed-effects, 1979-2010)

\begin{tabular}{|c|c|c|c|c|c|c|}
\hline \multirow{3}{*}{$\frac{\text { Dependent Variable: }}{\text { Disaster Variable }}$} & \multicolumn{4}{|c|}{$\Delta \ln$ GDP per capita } & \multicolumn{2}{|c|}{$(\mathrm{N}=3,099 ;$ Countries $=108)$} \\
\hline & \multicolumn{2}{|l|}{ GeoMet } & \multicolumn{2}{|l|}{ EM-DAT } & \multicolumn{2}{|c|}{ NatCatSERVICE } \\
\hline & (1) & (2) & (3) & (4) & (5) & (6) \\
\hline EMDAT All Disaster $_{i, t}$ & & & $\begin{array}{c}-0.438 \\
(0.69)\end{array}$ & & & \\
\hline EMDAT Large Disaster $_{i, t}$ & & & & $\begin{array}{l}-3.509 \\
(2.36)\end{array}$ & & \\
\hline NatCatSERVICE All Disaster $_{i, t}$ & & & & & $\begin{array}{l}0.001 \\
(0.07)\end{array}$ & \\
\hline NatCatSERVICE Large Disaster $_{i, t}$ & & & & & & $\begin{array}{l}-4.876 \\
(3.89)\end{array}$ \\
\hline Disaster Index $_{i, t}$ & $\begin{array}{c}-0.023^{*} \\
(0.01)\end{array}$ & & & & & \\
\hline Disaster Index ${ }_{i, t}$, weighted & & $\begin{array}{c}-0.064^{* * *} \\
(0.02)\end{array}$ & & & & \\
\hline Controls & & & & & & \\
\hline $\ln$ GDP per capita i $_{i, t-1}$ & $\begin{array}{c}-0.076^{* * *} \\
(0.01)\end{array}$ & $\begin{array}{c}-0.076^{* * *} \\
(0.01)\end{array}$ & $\begin{array}{c}-0.076^{* * *} \\
(0.01)\end{array}$ & $\begin{array}{c}-0.076^{* * *} \\
(0.01)\end{array}$ & $\begin{array}{c}-0.076^{* * *} \\
(0.01)\end{array}$ & $\begin{array}{c}-0.076^{* * *} \\
(0.01)\end{array}$ \\
\hline Adjusted $R^{2}$ & 0.181 & 0.181 & 0.181 & 0.181 & 0.181 & 0.181 \\
\hline $\begin{array}{l}\text { Note: }{ }^{* * *},{ }^{* *},{ }^{*} \text { denote significance } \\
\text { included but not reported. Robu } \\
\text { countries. Column (1) uses the s } \\
\text { measure weighted by the inverse } \\
\text { The decision rule for large-scale } \\
\text { 'great natural disasters' by Munic } \\
1,000 \text { or more were killed, or (ii) a } \\
\text { using the deflator on US dollars fr }\end{array}$ & $\begin{array}{l}\text { at the } 1 \%, \\
\text { st standard } \\
\text { imple disas } \\
\text { of the withi } \\
\text { disasters fro } \\
\text { h Re (2006) } \\
\text { t least } 1 \text { bill } \\
\text { om WDI), a }\end{array}$ & $\begin{array}{l}5 \% \text {, and } 10 \% \\
1 \text { errors rep } \\
\text { ster index n } \\
\text { n country s } \\
\text { om EM-DA? } \\
\text { and the U } \\
\text { lion US doll } \\
\text { nd with EM }\end{array}$ & $\begin{array}{l}\text { level, resp } \\
\text { orted in pa } \\
\text { leasure, wh } \\
\text { tandard dey } \\
\text { and NatC } \\
\text { nited Natio } \\
\text { ar monetar } \\
\text {-DAT also if }\end{array}$ & $\begin{array}{l}\text { ectively. Co } \\
\text { enthesis. } \\
\text { ile column } \\
\text { iation of ec } \\
\text { atSERVICE } \\
\text { ns. Disaste } \\
\text { damage (1 } \\
\text { (iii) } 100,00\end{array}$ & $\begin{array}{l}\text { untry and t } \\
\text { Unbalanced } \\
\text { (2) uses th } \\
\text { ch respecti } \\
\text { bases on th } \\
\text { rs are defin } \\
\text { made comp } \\
0 \text { or more a }\end{array}$ & $\begin{array}{l}\text { e fixed effects } \\
\text { anel with } 108 \\
\text { disaster index } \\
\text { disaster type. } \\
\text { convention of } \\
\text { as large if (i) } \\
\text { ble over time } \\
\text { cted. }\end{array}$ \\
\hline
\end{tabular}


TABLE B-V

GDP per capita Growth and Natural Disasters, First-Differenced Model (1979-2010)

\begin{tabular}{|c|c|c|c|c|c|c|}
\hline \multirow{3}{*}{$\begin{array}{l}\text { Dependent Variable: } \\
\text { Disaster Variable }\end{array}$} & \multicolumn{4}{|c|}{$\Delta \ln$ GDP per capita } & \multicolumn{2}{|c|}{$(\mathrm{N}=2,990 ;$ Countries $=108)$} \\
\hline & \multicolumn{2}{|l|}{ GeoMet } & \multicolumn{2}{|l|}{ EM-DAT } & \multicolumn{2}{|c|}{ NatCatSERVICE } \\
\hline & (1) & (2) & (3) & (4) & $(5)$ & $(6)$ \\
\hline$\Delta$ EMDAT All Disaster $_{i, t}$ & & & $\begin{array}{l}-0.434 \\
(0.23)\end{array}$ & & & \\
\hline$\Delta$ EMDAT Large Disaster $r_{i, t}$ & & & & $\begin{array}{l}-1.745 \\
(1.57)\end{array}$ & & \\
\hline$\Delta$ NatCatSERVICE All Disaster ${ }_{i, t}$ & & & & & $\begin{array}{l}0.020 \\
(0.05)\end{array}$ & \\
\hline$\Delta$ NatCatSERVICE Large Disaster ${ }_{i, t}$ & & & & & & $\begin{array}{l}-1.491 \\
(2.84)\end{array}$ \\
\hline$\Delta$ Disaster Index ${ }_{i, t}$ & $\begin{array}{c}-0.043^{* * *} \\
(0.01)\end{array}$ & & & & & \\
\hline$\Delta$ Disaster Index Int, , weighted & & $\begin{array}{c}-0.032^{*} \\
(0.02)\end{array}$ & & & & \\
\hline Controls & & & & & & \\
\hline$\Delta \ln$ GDP per capita ${ }_{i, t-1}$ & $\begin{array}{c}0.201^{* * *} \\
(0.04)\end{array}$ & $\begin{array}{c}0.201^{* * *} \\
(0.04)\end{array}$ & $\begin{array}{c}0.201^{* * *} \\
(0.04)\end{array}$ & $\begin{array}{c}0.201^{* * *} \\
(0.04)\end{array}$ & $\begin{array}{c}0.201^{* * *} \\
(0.04)\end{array}$ & $\begin{array}{c}0.201^{* * *} \\
(0.04)\end{array}$ \\
\hline Adjusted $R^{2}$ & 0.146 & 0.146 & 0.146 & 0.146 & 0.146 & 0.146 \\
\hline
\end{tabular}

Note: ${ }^{* * *},{ }^{* *},{ }^{*}$ denote significance at the $1 \%, 5 \%$, and $10 \%$ level, respectively. Time fixed effects included but not reported. All columns use a first-difference approach. Robust standard errors reported in parenthesis. Unbalanced panel with 108 countries. Column (1) uses the simple disaster index measure, while column (2) uses the disaster index measure weighted by the inverse of the within country standard deviation of each respective disaster type. The decision rule for large-scale disasters from EM-DAT and NatCatSERVICE bases on the convention of 'great natural disasters' by Munich Re (2006) and the United Nations. Disasters are defined as large if (i) 1,000 or more were killed, or (ii) at least 1 billion US dollar monetary damage (made comparable over time using the deflator on US dollars from WDI), and with EM-DAT also if (iii) 100,000 or more affected. 
TABLE B-VI

GDP per capita and Natural Disasters, Levels (1979-2010)

\begin{tabular}{|c|c|c|c|c|}
\hline Dependent Variable: & \multicolumn{4}{|c|}{ ln GDP per capita } \\
\hline Sample: & $\begin{array}{l}\text { MRW } \\
\text { (1) }\end{array}$ & $\begin{array}{c}\text { Full } \\
(2)\end{array}$ & $\begin{array}{c}\text { Non-OECD } \\
\text { (3) }\end{array}$ & $\begin{array}{l}\text { OECD } \\
(4)\end{array}$ \\
\hline \multicolumn{5}{|c|}{ PANEL A: Disaster Index } \\
\hline Disaster index ${ }_{i, t}$ & $\begin{array}{c}-0.553^{* * *} \\
(0.11)\end{array}$ & $\begin{array}{c}-0.560^{* * *} \\
(0.09)\end{array}$ & $\begin{array}{c}-0.553^{* * *} \\
(0.12)\end{array}$ & $\begin{array}{l}-0.692 \\
(0.86)\end{array}$ \\
\hline Observations & 1,474 & 1,787 & 1,282 & 505 \\
\hline Adjusted $R^{2}$ & 0.885 & 0.871 & 0.863 & 0.969 \\
\hline \multicolumn{5}{|c|}{ PANEL B: Disaster Index, weighted } \\
\hline Disaster index, weighted ${ }_{i, t}$ & $\begin{array}{c}-0.249^{* *} \\
(0.11)\end{array}$ & $\begin{array}{c}-0.279^{* * *} \\
(0.10)\end{array}$ & $\begin{array}{c}-0.292^{* *} \\
(0.14)\end{array}$ & $\begin{array}{l}0.725 \\
(1.19)\end{array}$ \\
\hline Observations & 1,474 & 1,787 & 1,282 & 505 \\
\hline Adjusted $R^{2}$ & 0.881 & 0.868 & 0.859 & 0.969 \\
\hline \multicolumn{5}{|c|}{ PANEL C: Disaster Intensity Measures } \\
\hline Richter scale $_{i, t}$ & $\begin{array}{c}-1.555^{* * *} \\
(0.35)\end{array}$ & $\begin{array}{c}-1.535^{* * *} \\
(0.29)\end{array}$ & $\begin{array}{c}-1.407^{* * *} \\
(0.34)\end{array}$ & $\begin{array}{l}21.695 \\
(18.78)\end{array}$ \\
\hline $\mathrm{VEI}_{i, t}$ & $\begin{array}{c}-0.006 \\
(0.06)\end{array}$ & $\begin{array}{c}-0.007 \\
(0.06)\end{array}$ & $\begin{array}{c}-0.026 \\
(0.06)\end{array}$ & $\begin{array}{l}-0.123 \\
(0.13)\end{array}$ \\
\hline Wind speed $_{i, t}$ & $\begin{array}{c}-2.147^{* * *} \\
(0.67)\end{array}$ & $\begin{array}{c}-2.303^{* * *} \\
(0.43)\end{array}$ & $\begin{array}{c}-2.318^{* * *} \\
(0.54)\end{array}$ & $\begin{array}{l}-4.973 \\
(4.91)\end{array}$ \\
\hline Positive $\Delta \operatorname{rain}_{i, t}$ & $\begin{array}{c}0.122^{*} \\
(0.07)\end{array}$ & $\begin{array}{l}0.076 \\
(0.08)\end{array}$ & $\begin{array}{l}0.059 \\
(0.07)\end{array}$ & $\begin{array}{l}1.798 \\
(1.98)\end{array}$ \\
\hline Drought $_{i, t}$ (dummy) & $\begin{array}{l}0.003 \\
(0.01)\end{array}$ & $\begin{array}{l}-0.005 \\
(0.01)\end{array}$ & $\begin{array}{l}0.013 \\
(0.01)\end{array}$ & $\begin{array}{c}-0.064 \\
(0.12)\end{array}$ \\
\hline$\Delta$ temperature $_{i, t}$ & $\begin{array}{l}0.461 \\
(0.87)\end{array}$ & $\begin{array}{l}-0.004 \\
(0.08)\end{array}$ & $\begin{array}{l}-0.111 \\
(0.10)\end{array}$ & $\begin{array}{l}0.194 \\
(0.15)\end{array}$ \\
\hline Observations & 1,474 & 1,787 & 1,282 & 505 \\
\hline Adjusted $R^{2}$ & 0.885 & 0.871 & 0.863 & 0.969 \\
\hline
\end{tabular}


TABLE B-VII GDP per capita and Natural Disasters, Instrumented (1979-2010)

Dependent Variable: $\Delta \ln$ GDP per capita

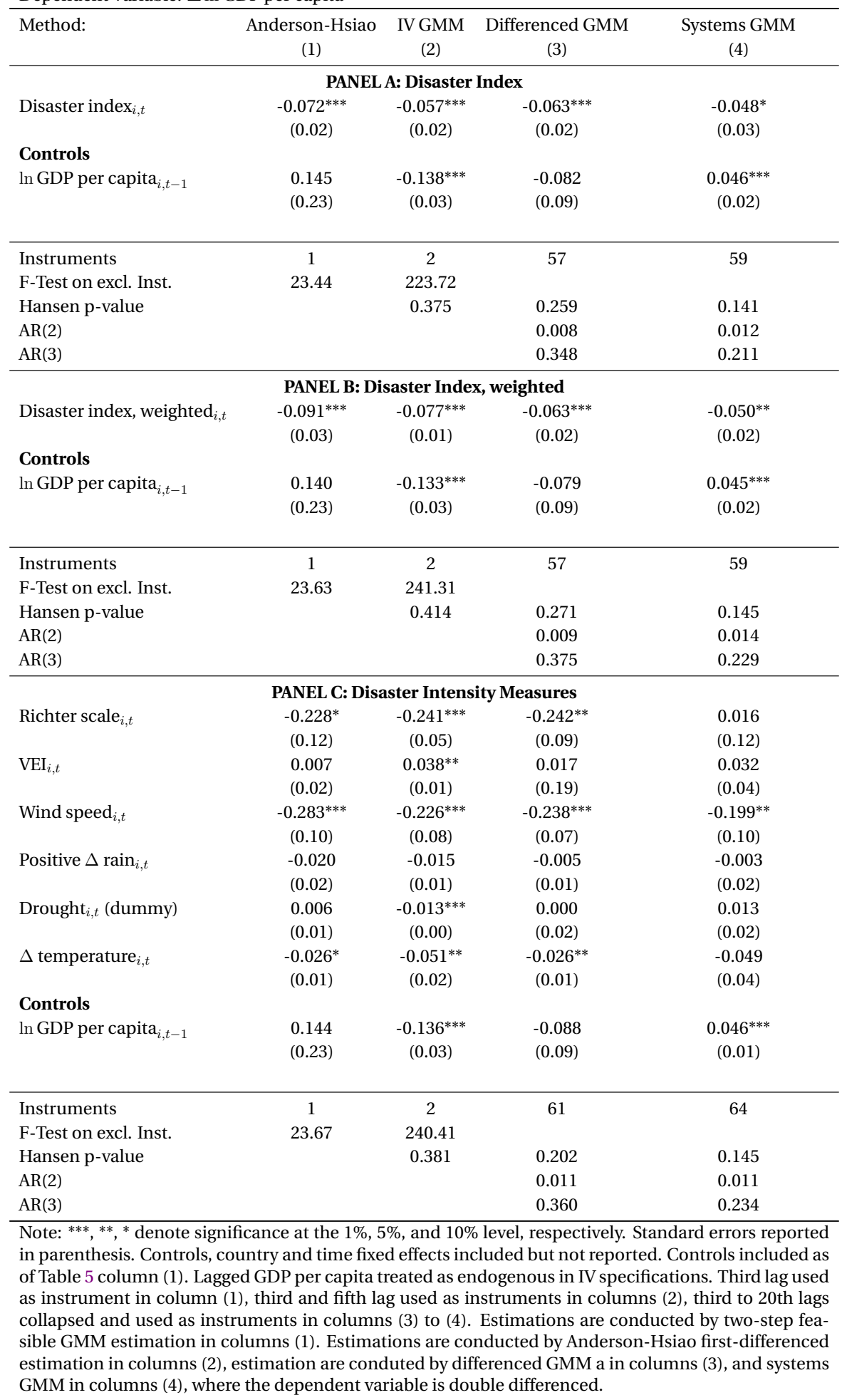


TABLE B-VIII

Summary Table, Various Samples

\begin{tabular}{|c|c|c|c|c|}
\hline Variable & Mean & Std. Dev. & Mean & Std. Dev. \\
\hline & \multicolumn{2}{|c|}{ Non-OECD $(\mathrm{N}=1,282)$} & \multicolumn{2}{|c|}{$\operatorname{OECD}(\mathrm{N}=505)$} \\
\hline Richter scale $_{i, t}$ & 0.001 & 0.007 & 0.0002 & 0.0003 \\
\hline $\mathrm{VEI}_{i, t}$ & 0.010 & 0.050 & 0.005 & 0.018 \\
\hline 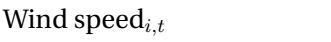 & 0.011 & 0.053 & 0.004 & 0.005 \\
\hline Positive $\Delta$ rain $_{i, t}$ & 0.012 & 0.062 & 0.002 & 0.003 \\
\hline Drought $_{i, t}$ & 0.013 & 0.149 & 0.0003 & 0.008 \\
\hline 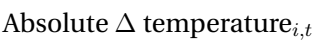 & 0.009 & 0.045 & 0.009 & 0.016 \\
\hline Disaster Index $_{i, t}$ & 0.050 & 0.234 & 0.016 & 0.019 \\
\hline \multirow[t]{2}{*}{ Disaster Index, weighted $_{i, t}$} & 0.052 & 0.246 & 0.012 & 0.013 \\
\hline & \multicolumn{2}{|c|}{ Low/Middle ( $\mathrm{N}=1,221)$} & \multicolumn{2}{|c|}{ High $(\mathrm{N}=622)$} \\
\hline Richter scale $_{i, t}$ & 0.0003 & 0.0005 & 0.002 & 0.010 \\
\hline $\mathrm{VEI}_{i, t}$ & 0.011 & 0.051 & 0.004 & 0.016 \\
\hline Wind speed $_{i, t}$ & 0.002 & 0.003 & 0.022 & 0.075 \\
\hline Positive $\Delta$ rain $_{i, t}$ & 0.002 & 0.004 & 0.022 & 0.088 \\
\hline Drought $_{i, t}$ & 0.005 & 0.028 & 0.016 & 0.211 \\
\hline 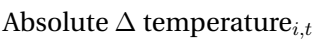 & 0.005 & 0.029 & 0.018 & 0.051 \\
\hline Disaster Index $_{i, t}$ & 0.010 & 0.014 & 0.098 & 0.329 \\
\hline \multirow[t]{2}{*}{ Disaster Index, weighted $_{i, t}$} & 0.009 & 0.142 & 0.099 & 0.346 \\
\hline & \multicolumn{2}{|c|}{ Democratic $(\mathrm{N}=1,355)$} & \multicolumn{2}{|c|}{ Autocratic $(\mathrm{N}=432)$} \\
\hline Richter scale $_{i, t}$ & 0.0005 & 0.0012 & 0.002 & 0.012 \\
\hline $\mathrm{VEI}_{i, t}$ & 0.012 & 0.049 & 0.002 & 0.010 \\
\hline Wind speed $_{i, t}$ & 0.004 & 0.008 & 0.025 & 0.090 \\
\hline Positive $\Delta$ rain $_{i, t}$ & 0.004 & 0.011 & 0.025 & 0.104 \\
\hline Drought $_{i, t}$ & 0.008 & 0.136 & 0.014 & 0.091 \\
\hline Absolute $\Delta$ temperature $_{i, t}$ & 0.009 & 0.039 & 0.010 & 0.037 \\
\hline Disaster Index $_{i, t}$ & 0.019 & 0.035 & 0.108 & 0.392 \\
\hline Disaster Index, weighted $_{i, t}$ & 0.018 & 0.036 & 0.113 & 0.412 \\
\hline
\end{tabular}


TABLE B-IX

Growth effects of natural disasters by type of disaster (1979-2010)

Dependent Variable: $\quad \Delta \ln$ GDP per capita

\begin{tabular}{|c|c|c|c|c|c|c|c|}
\hline & (1) & (2) & (3) & (4) & (5) & (6) & (7) \\
\hline Richter scale $_{i, t}$ & $\begin{array}{c}-0.283^{* * *} \\
(0.07)\end{array}$ & & & & & & $\begin{array}{c}-0.202^{* * *} \\
(0.05)\end{array}$ \\
\hline $\operatorname{VEI}_{i, t}$ & & $\begin{array}{l}0.027^{* *} \\
(0.01)\end{array}$ & & & & & $\begin{array}{c}0.027^{* *} \\
(0.01)\end{array}$ \\
\hline Wind speed $_{i, t}$ & & & $\begin{array}{c}-0.200^{* * *} \\
(0.06)\end{array}$ & & & & $\begin{array}{c}-0.192^{* * *} \\
(0.06)\end{array}$ \\
\hline Positive $\Delta \operatorname{rain}_{i, t}$ & & & & $\begin{array}{l}-0.015 \\
(0.01)\end{array}$ & & & $\begin{array}{r}-0.009 \\
(0.01)\end{array}$ \\
\hline Drought $_{i, t}$ (dummy) & & & & & $\begin{array}{c}-0.009^{* * *} \\
(0.00)\end{array}$ & & $\begin{array}{c}-0.010^{* * *} \\
(0.00)\end{array}$ \\
\hline$\Delta$ temperature $_{i, t}$ & & & & & & $\begin{array}{l}0.048 \\
(0.08)\end{array}$ & $\begin{array}{l}-0.052 \\
(0.11)\end{array}$ \\
\hline Adjusted $R^{2}$ & 0.216 & 0.216 & 0.217 & 0.216 & 0.216 & 0.216 & 0.215 \\
\hline
\end{tabular}

TABLE B-X

GDP per capita and Natural Disasters, Lags (1979-2010)

\begin{tabular}{|c|c|c|c|c|c|c|c|c|}
\hline Dependent Variable: & $\Delta \ln \mathrm{GDP}$ & er capita $(N=1$ & 37) & & & & & \\
\hline Disaster Variable : & $\begin{array}{l}\text { Disaster } \\
\text { index } \\
(1)\end{array}$ & $\begin{array}{l}\text { Disaster index, } \\
\text { weighted } \\
\text { (2) }\end{array}$ & $\begin{array}{l}\text { Richter } \\
\text { scale } \\
(3)\end{array}$ & $\begin{array}{l}\text { VEI } \\
(4)\end{array}$ & $\begin{array}{l}\text { Wind } \\
\text { speed } \\
(5)\end{array}$ & $\begin{array}{l}\text { Positive } \\
\Delta \text { rain } \\
\quad(6)\end{array}$ & $\begin{array}{c}\text { Drought } \\
\text { (dummy) } \\
\text { (7) }\end{array}$ & $\begin{array}{l}\Delta \text { temp- } \\
\text { erature } \\
\quad(8)\end{array}$ \\
\hline Disaster variable +0 years & $\begin{array}{c}-0.062^{* * *} \\
(0.02)\end{array}$ & $\begin{array}{l}-0.084 \\
(0.05)\end{array}$ & $\begin{array}{c}-0.261^{* * *} \\
(0.07)\end{array}$ & $\begin{array}{l}0.022 \\
(0.02)\end{array}$ & $\begin{array}{c}-0.246^{* * *} \\
(0.07)\end{array}$ & $\begin{array}{c}-0.018 \\
(0.03)\end{array}$ & $\begin{array}{c}-0.017^{* * *} \\
(0.00)\end{array}$ & $\begin{array}{l}-0.021 \\
(0.02)\end{array}$ \\
\hline Disaster variable +1 years & $\begin{array}{l}0.019 \\
(0.02)\end{array}$ & $\begin{array}{l}0.012 \\
(0.02)\end{array}$ & $\begin{array}{c}-0.336^{* * *} \\
(0.08)\end{array}$ & $\begin{array}{l}0.003 \\
(0.03)\end{array}$ & $\begin{array}{c}0.176^{* *} \\
(0.08)\end{array}$ & $\begin{array}{c}-0.059^{* * *} \\
(0.02)\end{array}$ & $\begin{array}{c}-0.031^{* * *} \\
(0.01)\end{array}$ & $\begin{array}{l}0.021 \\
(0.04)\end{array}$ \\
\hline Disaster variable +2 years & $\begin{array}{c}-0.093^{* * *} \\
(0.02)\end{array}$ & $\begin{array}{c}-0.071^{* * *} \\
(0.02)\end{array}$ & $\begin{array}{c}-0.220^{* * *} \\
(0.08)\end{array}$ & $\begin{array}{c}-0.004 \\
(0.01)\end{array}$ & $\begin{array}{c}-0.362^{* * *} \\
(0.09)\end{array}$ & $\begin{array}{c}-0.036^{* * *} \\
(0.01)\end{array}$ & $\begin{array}{c}-0.003 \\
(0.01)\end{array}$ & $\begin{array}{l}0.057 \\
(0.04)\end{array}$ \\
\hline Disaster variable +3 years & $\begin{array}{l}0.022 \\
(0.02)\end{array}$ & $\begin{array}{c}-0.001 \\
(0.06)\end{array}$ & $\begin{array}{c}-0.470^{* * *} \\
(0.16)\end{array}$ & $\begin{array}{c}0.046^{* * *} \\
(0.02)\end{array}$ & $\begin{array}{c}0.135^{*} \\
(0.07)\end{array}$ & $\begin{array}{c}-0.056^{* * *} \\
(0.01)\end{array}$ & $\begin{array}{c}0.017^{* * *} \\
(0.00)\end{array}$ & $\begin{array}{l}-0.026 \\
(0.02)\end{array}$ \\
\hline Disaster variable +4 years & $\begin{array}{c}0.067^{* * *} \\
(0.02)\end{array}$ & $\begin{array}{l}-0.009 \\
(0.05)\end{array}$ & $\begin{array}{l}0.101 \\
(0.13)\end{array}$ & $\begin{array}{c}-0.014 \\
(0.01)\end{array}$ & $\begin{array}{c}0.291^{* * *} \\
(0.10)\end{array}$ & $\begin{array}{c}-0.014 \\
(0.04)\end{array}$ & $\begin{array}{c}-0.009 \\
(0.01)\end{array}$ & $\begin{array}{l}-0.048 \\
(0.03)\end{array}$ \\
\hline Disaster variable +5 years & $\begin{array}{l}0.008 \\
(0.01)\end{array}$ & $\begin{array}{l}-0.015 \\
(0.02)\end{array}$ & $\begin{array}{c}-0.209 \\
(0.14)\end{array}$ & $\begin{array}{l}-0.053 \\
(0.03)\end{array}$ & $\begin{array}{l}0.005 \\
(0.06)\end{array}$ & $\begin{array}{l}0.010 \\
(0.03)\end{array}$ & $\begin{array}{c}-0.024^{* * *} \\
(0.00)\end{array}$ & $\begin{array}{c}-0.052^{*} \\
(0.03)\end{array}$ \\
\hline Adjusted $R^{2}$ & 0.274 & 0.270 & 0.270 & 0.267 & 0.274 & 0.267 & 0.276 & 0.267 \\
\hline
\end{tabular}

Note: ${ }^{* * *},{ }^{* *},{ }^{*}$ denote significance at the $1 \%, 5 \%$, and $10 \%$ level, respectively. Standard errors reported in parenthesis. Controls, country and time fixed effects included but not reported. Controls included as of Table 5 column (2). 
TABLE B-XI

Robust: Macroeconomic Factors, Fixed Effects (1979-2010)

\begin{tabular}{|c|c|c|c|c|c|c|}
\hline \multirow[t]{2}{*}{ Dependent Variable: } & \multicolumn{6}{|c|}{$\Delta \ln$ GDP per capita } \\
\hline & $\begin{array}{c}\text { Institution } \\
\text { (1) }\end{array}$ & $\begin{array}{c}\text { Trade policy } \\
\text { openness } \\
\text { (2) }\end{array}$ & $\begin{array}{c}\text { Financial } \\
\text { openness } \\
\text { (3) }\end{array}$ & $\begin{array}{c}\text { Institution } \\
\text { (4) }\end{array}$ & $\begin{array}{c}\text { Trade policy } \\
\text { openness } \\
\text { (5) }\end{array}$ & $\begin{array}{c}\text { Financial } \\
\text { openness } \\
\text { (6) }\end{array}$ \\
\hline & \multicolumn{6}{|c|}{ PANEL A: DISASTER INDEXES } \\
\hline & \multicolumn{3}{|c|}{ Disaster Index } & \multicolumn{3}{|c|}{ Disaster Index, weighted } \\
\hline Disaster index $_{i, t}$ & $\begin{array}{c}-0.296^{* * *} \\
(0.09)\end{array}$ & $\begin{array}{c}-0.144 \\
(0.31)\end{array}$ & $\begin{array}{c}-0.356^{* * *} \\
(0.11)\end{array}$ & $\begin{array}{c}-0.357^{* * *} \\
(0.10)\end{array}$ & $\begin{array}{c}-0.104 \\
(0.15)\end{array}$ & $\begin{array}{c}-0.337^{* * *} \\
(0.10)\end{array}$ \\
\hline Disaster index $_{i, t} \times$ Polity $_{i, t-1}$ & $\begin{array}{c}0.605^{* * *} \\
(0.20)\end{array}$ & & & $\begin{array}{c}0.701^{* * *} \\
(0.26)\end{array}$ & & \\
\hline Disaster index $_{i, t} \times \operatorname{Trade}_{i, t-1}$ & & $\begin{array}{l}0.098 \\
(0.31)\end{array}$ & & & $\begin{array}{l}0.043 \\
(0.15)\end{array}$ & \\
\hline Disaster index $_{i, t} \times$ Finance $_{i, t-1}$ & & & $\begin{array}{c}0.362^{* * *} \\
(0.12)\end{array}$ & & & $\begin{array}{c}0.331^{* * *} \\
(0.12)\end{array}$ \\
\hline Observations & 1,787 & 1,749 & 1,757 & 1,787 & 1,749 & 1,757 \\
\hline \multirow[t]{2}{*}{ Adjusted $R^{2}$} & 0.244 & 0.245 & 0.250 & 0.245 & 0.245 & 0.250 \\
\hline & \multicolumn{6}{|c|}{ PANEL B: PHYSICAL STRENGTH } \\
\hline Physical strength $_{i, t}$ & $\begin{array}{c}-5.692^{* * *} \\
(2.16)\end{array}$ & $\begin{array}{c}-1.463 \\
(3.56)\end{array}$ & $\begin{array}{c}-6.869^{* * *} \\
(1.84)\end{array}$ & $\begin{array}{c}-1.242^{* * *} \\
(0.36)\end{array}$ & $\begin{array}{c}-0.383 \\
(1.21)\end{array}$ & $\begin{array}{c}-1.691^{* * *} \\
(0.48)\end{array}$ \\
\hline Physical strength $_{i, t} \times$ Polity $_{i, t-1}$ & $\begin{array}{c}13.474^{* *} \\
(5.40)\end{array}$ & & & $\begin{array}{c}2.543^{* * *} \\
(0.80)\end{array}$ & & \\
\hline Physical strength $_{i, t} \times$ Trade $_{i, t-1}$ & & $\begin{array}{l}1.194 \\
(3.56)\end{array}$ & & & $\begin{array}{l}0.195 \\
(1.21)\end{array}$ & \\
\hline Physical strength $_{i, t} \times$ Finance $_{i, t-1}$ & & & $\begin{array}{c}7.975^{* * *} \\
(2.23)\end{array}$ & & & $\begin{array}{c}1.711^{* * *} \\
(0.53)\end{array}$ \\
\hline Observations & 1,787 & 1,749 & 1,757 & 1,787 & 1,749 & 1,757 \\
\hline Adjusted $R^{2}$ & 0.243 & 0.244 & 0.249 & 0.244 & 0.244 & 0.250 \\
\hline
\end{tabular}

Note: ${ }^{* * *},{ }^{* *},{ }^{*}$ denote significance at the $1 \%, 5 \%$, and $10 \%$ level, respectively. Standard errors reported in parenthesis. Controls, country and time fixed effects included but not reported. Controls included as of Table 5 column (1). 